\title{
The Vertical Farm: A Review of Developments and Implications for the Vertical City
}

\author{
Kheir Al-Kodmany \\ Department of Urban Planning and Policy, College of Urban Planning and Public Affairs, \\ University of Illinois at Chicago, Chicago, IL 60607, USA; kheir@uic.edu
}

Received: 10 January 2018; Accepted: 1 February 2018; Published: 5 February 2018

\begin{abstract}
This paper discusses the emerging need for vertical farms by examining issues related to food security, urban population growth, farmland shortages, "food miles", and associated greenhouse gas (GHG) emissions. Urban planners and agricultural leaders have argued that cities will need to produce food internally to respond to demand by increasing population and to avoid paralyzing congestion, harmful pollution, and unaffordable food prices. The paper examines urban agriculture as a solution to these problems by merging food production and consumption in one place, with the vertical farm being suitable for urban areas where available land is limited and expensive. Luckily, recent advances in greenhouse technologies such as hydroponics, aeroponics, and aquaponics have provided a promising future to the vertical farm concept. These high-tech systems represent a paradigm shift in farming and food production and offer suitable and efficient methods for city farming by minimizing maintenance and maximizing yield. Upon reviewing these technologies and examining project prototypes, we find that these efforts may plant the seeds for the realization of the vertical farm. The paper, however, closes by speculating about the consequences, advantages, and disadvantages of the vertical farm's implementation. Economic feasibility, codes, regulations, and a lack of expertise remain major obstacles in the path to implementing the vertical farm.
\end{abstract}

Keywords: advanced cultivation methods; innovative technologies; efficient food production; urban population increase; sustainability

\section{Introduction}

\subsection{Background}

This research stems from a larger research project that examined vertical density applications to the 21st Century City [1-3]. As cities try to cope with rapid population growth-adding 2.5 billion dwellers by 2050 - and grapple with destructive sprawl, politicians, planners and architects have become increasingly interested in the vertical city paradigm. Unfortunately, cities all over the world are grossly unprepared for embracing vertical density, because it may aggravate multidimensional sustainability challenges resulting in a "vertical sprawl" that could have worse consequences than "horizontal" sprawl. One key problem of future cities will be transporting large amount of food to serve dense population, and the vertical farm model offers a potential solution to this problem [1-5].

\subsection{Goals and Scope of the Study}

As urban population continues to grow and as arable land is diminishing rapidly across the globe, a fundamental change in food production is needed [4-7]. In particular, building-based urban agriculture is increasingly needed in dense urban environments and a review of current cultivation techniques and projects would likely to contribute positively to academic discussions [6-10]. This is particularly important since vertical farming engages multiple disciplines of natural sciences, 
architecture, and engineering and affects both people and the environment [9-11]. This paper attempts to answer the following questions:

- What is a vertical farm?

- What are the driving forces for building it?

- What are the involved high-tech farming methods?

- What are the salient project examples on vertical farming?

- What are the implications for the vertical city?

\subsection{Methods}

Currently, we witness a growing body of research on vertical farming. Studies and updates on the topic come in multiple forms including academic papers, professional reports, news articles, blogs, and websites, as demonstrated in this paper references. This paper pieces together these materials in attempt to answer the above questions. It examines a wide-range of literatures related to agronomy, urban agriculture, vertical farming, and rooftop farming. It also reviews involved technologies, current cultivation techniques, business models, and analyzes research projects.

This study evolved from anecdotal observations to systematic examination of involved technologies, actual and visionary projects of vertical farming. In the preliminary stage, surfing the Internet (website, blogs, movie clips) excited and fueled the research by informing about recent projects that utilize advanced technology. This sparked systematic examination of generic (secondary) and specialized (primary) literatures on vertical farming by using various online search engines and databases including Scopus, ProQuest, and Google Scholar. Researchers collected over 100 sources. These sources comprised $42 \%$ peer-reviewed academic journal articles, $28 \%$ books and book chapters, $6 \%$ theses, $9 \%$ conference papers, and $15 \%$ websites. Most of the reviewed literature is relatively recent, dating 2010-2017. The reviewed projects come mainly from North America, Europe, and Asia.

Overall, this study adopts a qualitative informative approach. The paper gathers complex technical information and makes them accessible to the non-specialists. Collectively, by reviewing, organizing, and collating information of various sources, the paper hopes to provide a better understanding of the theory and practice of vertical farming.

\subsection{What Is a Vertical Farm?}

Vertical farming seeks to ensure the sustainability of our cities proactively by addressing food security to the world's ever-increasing urban population [4-8]. In principle, it is a simple concept; farm up rather than out [8-10]. The body of literature on the subject distinguishes between three types of vertical farming [9-11]. The first type refers to the construction of tall structures with several levels of growing beds, often lined with artificial lights. This often modestly sized urban farm has been springing up around the world. Many cities have implemented this model in new and old buildings, including warehouses that owners repurposed for agricultural activities [8]. The second type of vertical farming takes place on the rooftops of old and new buildings, atop commercial and residential structures as well as on restaurants and grocery stores $[9,10]$. The third type of vertical farm is that of the visionary, multi-story building. In the past decade, we have seen an increasing number of serious visionary proposals of this type. However, none has been built. It is important, however, to note the connection between these three types, the success of modestly sized vertical farm projects and the maturation of their technologies will likely pave the way for the skyscraper farm [9].

Environmentalists, urban farmers, architects, agronomists, and public health experts, among others, have been joining this mini revolution as they partner to work out a way to salvage a food-scarce, ultra-urbanized future. A wide number of technology experts have converged on the concept of vertical farming, advancing the fields of robotics, aeroponics, aquaponics, and hydroponics. Nonprofits organizations, aiming to promote environmentalism and local economic prosperity, have been backing the vertical farm concept. Similarly, for-profit ventures that seek to meet the demand for local 
produce have supported this concept. Further, governments looking for ways to boost domestic food security have been funding these endeavors. Numerous countries including Korea, Japan, China, Germany, the United Arab Emirates, China, France, India, Sweden, Singapore, and the United States, have convened to discuss vertical farming. They have repeatedly endorsed the concept as integral to the long-term sustainability of their cities [9].

The idea of vertical farming is not entirely new. Examples of it can be found dating back to the ancient era in the Hanging Gardens of Babylon, one of Philon's Seven Wonders of the Ancient World, built around 600 BC. In 1915, Gilbert Ellis Bailey coined the term "vertical farming" and wrote a book titled "Vertical Farming". He argued that farming hydroponically in a controlled vertical environment would provide economic and environmental benefits. In the early 1930s, William Frederick Gericke pioneered hydroponics at the University of California at Berkley. In the 1980s, Åke Olsson, a Swedish ecological farmer, also proposed vertical farming as a means for producing vegetables in cities. He is known for having invented a spiral-shaped rail system for growing plants [4-9]. Around the turn of the century, Dickson Despommier, an American ecologist, and professor of public health, passionately revived the concept of vertical farming. He described the vertical farm as "the mass cultivation of plant and animal life for commercial purposes in skyscrapers. Using advanced greenhouse technology such as hydroponics and aeroponics, the vertical farm could theoretically produce fish, poultry, fruit, and vegetables" [7] (p. 15). The vertical farm is considered to promote sustainable agricultural practices more than that by conventional farming, which refers to large scale, outdoor agriculture that embraces systems that engage heavy irrigation, intensive tillage and excessive use of fertilizers, pesticides, and herbicides [5] (p. 16).

\subsection{Why Vertical Farms?}

\subsubsection{Food Security}

Food security has become an increasingly important issue. Demographers anticipate that urban population will dramatically increase in the coming decades. At the same time, land specialists (e.g., agronomists, ecologists, and geologists) warn of rising shortages of farmland [4-6]. For these reasons, food demand could exponentially surpass supply, leading to global famine. The United Nation (UN) estimates that the world's population will increase by $40 \%$, exceeding 9 billion people by the year 2050 [12]. The UN also projects that $80 \%$ of the world's population will reside in cities by this time. Further, it predicts that by 2050 we will need $70 \%$ more food to meet the demands of 3 billion more inhabitants worldwide [12]. Food prices have already skyrocketed in the past decades, and farmers predict that prices will increase further as oil costs increase and water, energy, and agricultural resources diminish [7-10]. The sprawling fringes of suburban development continue to eat up more and more farmland. On the other hand, urban agriculture has been facing problems due to land scarcity and high costs. We desperately need transformative solutions to combat this immense global challenge [8-11].

The logic of vertical farming is simple: produce more food on less land $[10,11]$. The same rationale that we use to stack homes and offices in limited and expensive land, such as in Hong Kong or Manhattan, can apply to farming. Proponents of the vertical farm claim that it would create compact and self-sufficient ecosystems that cover multiple functions, from food production to waste management. Vertical farming could enable food production in an efficient and sustainable manner, save water and energy, enhance the economy, reduce pollution, provide new employment opportunities, restore ecosystems, and provide access to healthy food. In a controlled environment, crops will be less subject to the vagaries of climate, infestation, the nutrient cycle, crop rotation, polluted water runoff, pesticides, and dust [12]. As such, indoor farming could possibly offer a healthier environment to grow food $[5,13]$. Since indoor farming operates year-round and is independent of weather conditions, it could also provide greater yields and perpetual income [14]. Furthermore, indoor farming provides a low-impact system that can significantly reduce travel costs, as well as reduce GHG emissions, by cutting down on travel distances between distant farms and local market [13,15]. 
Also, vertical farming could ignite local economies by providing much needed "green collar" jobs to urban areas [5,13].

Importantly, vertical farms could help in addressing the problem of farmland shortages $[4,5,7]$. According to the United Nations' Food and Agriculture Organization, there was 0.42 ha $(1 \mathrm{ac})$ of arable land per person on earth in 1961. By 2002, because of population growth and urbanization, that number has dropped by nearly half, to 0.23 ha (0.5 ac) [5]. In 2011, the United Nations completed a global assessment of the planet's land resources, determining that a quarter of all arable land is highly degraded. Further, since 1960, one million farmers in the United States have gave up farming [5-19]. Today, the country suffers from " 23 million food deserts, defined by the U.S. Department of Agriculture (USDA) as urban neighborhoods and rural towns without ready access to fresh, healthy, and affordable food" [20] (p. 32). Dickson Despommier explains that current agricultural supply will soon become largely inadequate. That is, on average, every human being needs 1500 calories daily, and in order to meet such demand, we will need to add to existing agricultural land an area as big as Brazil by 2050 [7].

\subsubsection{Climate Change}

Climate change has contributed to the decrease of arable land. Through flooding, hurricane, storms, and drought, valuable agricultural land has been decreased drastically, thereby damaging the world economy $[7,11,12,18]$. For example, due to an extended drought in 2011, the United States lost a grain crop assessed at $\$ 110$ billion $[11,19,20]$. Scientists predict that climate change and the adverse weather conditions it brings will continue to happen at an increasing rate. These events will lead to the despoliation of large tracts of arable land, rendering them useless for farming. It is common for governments to subsidize traditional farming heavily through mechanisms such as crop insurance from natural causes [6,21,22]. Furthermore, traditional farming requires substantial quantities of fossil fuels to carry out agricultural activities (e.g., plowing, applying fertilizers, seeding, weeding, and harvesting), which amounts to over $20 \%$ of all gasoline and diesel fuel consumption in the United States. We need to understand that "food miles" refers to the distance crops travel to reach centralized urban populations. On average, food travels 1500 miles from the farm field to the dinner table [8,15]. In special circumstances—cold weather, for example—food miles can rise drastically as stores, restaurants, and hospitals fly produce in from overseas to meet demands. On a regular basis, over $90 \%$ of the food in major U.S. cities is shipped from outside. A 2008 study at Carnegie Mellon concluded that food delivery is responsible for 0.4 tons of carbon dioxide emissions per household per year $[23,24]$. This is especially important given the increasing distance between farms and cities from global urbanization. Sadly, the resulting greenhouse gas emissions from food transport and agricultural activities have contributed to climate change (Figure 1).

\subsubsection{Urban Density}

Vertical farming offers advantages over "horizontal" urban farming for the former frees land for incorporating more urban activities (i.e., housing more people, services, and amenities) [7]. Research has revealed that designating urban land to farming results in decreased population density, which leads to longer commutes. "If America replaced just $7.9 \%$ of its whopping one billion acres of crop and pastureland with urban farms, then metropolitan area densities would be cut in half" [4] (p. 71). Lower density living incurs higher energy use and generates more air and water pollution. The National Highway Travel Survey (NHTS) indicates, "If we decrease urban density by 50\%, households will purchase an additional 100 gallons of gas per year. The increased gas consumption resulting from moving a relatively small percentage of farmland into cities would generate an extra 1.77 tons of carbon dioxide per household per year" [23]. Despommier details space efficiency of vertical farms. He suggested that a 30-story building (about $100 \mathrm{~m}$ high) with a basal area of $2.02 \mathrm{ha}$ ( $5 \mathrm{ac}$ ) would be able to produce a crop yield equivalent to $971.2 \mathrm{ha}(2400 \mathrm{ac})$ of conventional horizontal farming. This means that the production of one high-rise farm would be equivalent to 480 conventional horizontal farms [24,25]. 


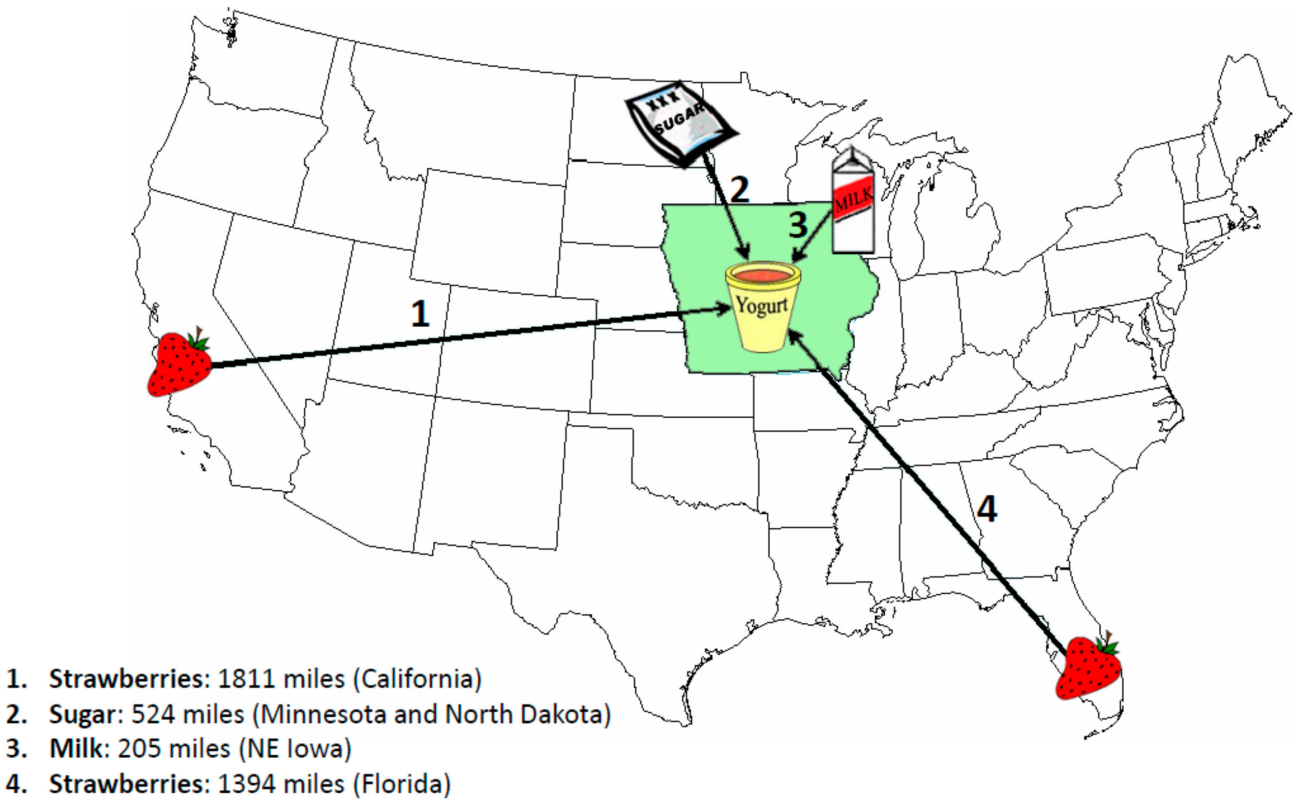

Figure 1. Food travels great distances from farm fields to dinner table. The map illustrates the case of the travel of basic ingredients of a strawberry yogurt can (Adapted from [8]).

\subsubsection{Health}

Conventional farming practices often stress profit and commercial gain while paying inadequate attention to inflicted harm on the health of both human and the natural environment $[7,8,10]$. These practices repeatedly cause erosion, contaminate soil, and generate excessive water waste. Regarding human well-being, the World Health Organization has determined that over half of the world's farms still use raw animal waste as fertilizer which may attract flies, and may contain weed seeds or disease that can be transmitted to plants [1]. Consequently, people's health is adversely affected when they consume such produce.

Further, growing crops in a controlled indoor environment would provide the benefit of reducing the excessive use of pesticide and herbicide, which create polluting agricultural runoff [25]. According to Renee Cho, "In a contained environment, pests, pathogens, and weeds have a much harder time infiltrating and destroying crops" [25]. When excess fertilizer washes into water bodies (e.g., rivers, streams, and oceans), a high concentration of nutrients is created (called eutrophication), which could disturb the ecological equilibrium. For example, eutrophication may accelerate the proliferation of algae. However, when it dies, microbes consume algae and suck all the oxygen in water, resulting in dead aquatic zones [8]. "As of 2008, there were 405 dead zones around the world" [25].

Further, indoor vertical farming employs high-tech growing methods that use little water (about $1 / 10$ th of that used in traditional farming) by offering precision irrigation and efficient scheduling $[25,26]$. This can have a significant ameliorative effect since demands on water will increase as the urban population grows. Agricultural activities use more than two-thirds of the world's fresh water, and farmers are losing the batter for crop water because urban areas are expanding and consuming more water. The water crisis is likely to become severer as climate change causes warmer temperatures and proliferates more droughts [25].

\subsubsection{The Ecosystem}

Traditional agriculture has been encroaching upon natural ecosystems for millennia. According to Dickson Despommier, "Farming has upset more ecological processes than anything else- it is the most destructive process on earth" [4] (p. 7). In the past half century or so, the Brazilian rainforest has been severely impacted by agricultural encroachment, with some $1,812,992 \mathrm{~km}^{2}\left(700,000 \mathrm{mi}^{2}\right)$ of 
hardwood forest being cleared for farmland [4]. Despommier suggested that encroachment on these ancient ecosystems is furthering climate change. In this way, indoor vertical farming can reduce the agricultural impact on the world's ecosystems by restoring biodiversity and reducing the negative influences of climate change. If cities employed vertical farms to produce merely $10 \%$ of the ground area they consume, this might help to reduce $\mathrm{CO}_{2}$ emissions enough to develop better technological innovations for improving the condition of the biosphere long-term. By eliminating fertilizer runoff, coastal and river water could be restored, and fish stock of wild fish could increase. Wood, et al. summarize this point by stating "The best reason to consider converting most food production to vertical farming is the promise of restoring [the] services and functions [of ecosystems]" [26] (p. 110).

\subsubsection{Economics}

Proponents of the vertical farm also argue that it will supply competitive food prices [27]. The rising expense of traditional farming is quickly narrowing the cost gap. For example, when vertical farms are located strategically in urban areas, it would be possible to sell produce directly to the consumer, reducing transportation costs by removing the intermediary, which can constitute up to $60 \%$ of costs [27]. Vertical farms also utilize advanced technologies and intensive farming methods that can exponentially increase production. Researchers have been optimizing indoor farming by calibrating, tuning and adjusting a wide-range of variables including light intensity, light color, space temperature, crop and root, $\mathrm{CO}_{2}$ contents, soil, water, and air humidity [27-29]. In addition, vertical farming provides an opportunity to support the local economy. Abandoned urban buildings can be converted into vertical farms to provide healthy food in neighborhoods where fresh produce is scarce. Additionally, the high-tech environment of indoor farming can make it fun to farm. Hence, a technology-savvy younger generation has been enticed by the practice, grooming a new breed of farmers. Further, vertical farming provides impetus in the development of innovative agricultural technologies. Finally, it could reconnect city dwellers with nature through the activity of farming [27].

\section{High-Tech Indoor Farming}

\subsection{Farming Methods}

Researchers have advanced myriad methods of urban and vertical farming in the hopes of contributing to sustainable food production. Advanced farming methods could provide greater yields and use far less water than traditional farming $[17,18]$. The design, layout, and configuration of these high-tech farms would provide optimal light exposure, along with precisely measured nutrients for each plant. Designed to grow in a controlled, closed-loop environment, these farms would eliminate the need for harmful herbicides and pesticides, maximizing nutrition, and food value in the process. Indoor farmers could also "engineer" the taste of produce to cater to people's preferences [30]. Researches intend to develop, refine, and adapt these systems so that they can be ultimately deployed anywhere in the world and provide maximum production and minimum environmental impacts. They represent a paradigm shift in farming and food production and scholars view them as suitable for city farming where land availability is limited [5]. These systems (mainly hydroponics, aeroponics, and aquaponics) and associated technologies are rapidly evolving, diversifying, and improving (Table 1). The paper explains these systems in a gradual manner, from simple to complex. 
Table 1. High-Tech Indoor Farming.

\begin{tabular}{|c|c|c|c|}
\hline $\begin{array}{l}\text { Farming } \\
\text { Method }\end{array}$ & Key Characteristics & Major Benefits & $\begin{array}{c}\text { Common/Applicable } \\
\text { Technologies }\end{array}$ \\
\hline Hydroponics & $\begin{array}{l}\text { Soilless based, uses water as } \\
\text { the growing medium }\end{array}$ & $\begin{array}{l}\text { Fosters rapid plant growth; } \\
\text { Reduces, even eliminates } \\
\text { soil-related cultivation } \\
\text { problems; Decreases the use of } \\
\text { fertilizers or pesticides. }\end{array}$ & \multirow{3}{*}{$\begin{array}{l}\text { Computerized and monitoring } \\
\text { systems; Cell phones, laptops, } \\
\text { and tablets; Food growing apps; } \\
\text { Remote control systems and } \\
\text { software (farming-from-afar } \\
\text { systems); Automated racking, } \\
\text { stacking systems, moving belts, } \\
\text { and tall towers; Programmable } \\
\text { LED lighting systems; Renewable } \\
\text { energy applications (solar panels, } \\
\text { wind turbines, geothermal, etc.); } \\
\text { Closed-loop systems, anaerobic } \\
\text { digesters; Programmable nutrient } \\
\text { systems; Climate control, HVAC } \\
\text { systems; Water recirculating and } \\
\text { recycling systems; Rainwater } \\
\text { collectors; Insect-killing systems; } \\
\text { Robots }\end{array}$} \\
\hline Aeroponics & $\begin{array}{l}\text { A variant of hydroponics; } \\
\text { it involves spraying } \\
\text { the roots of plants with mist } \\
\text { or nutrient solutions. }\end{array}$ & $\begin{array}{l}\text { In addition to benefits } \\
\text { mentioned above, Aeroponics } \\
\text { requires less water. }\end{array}$ & \\
\hline Aquaponics & $\begin{array}{l}\text { It integrates aquaculture } \\
\text { (fish farming) with } \\
\text { hydroponics. }\end{array}$ & $\begin{array}{l}\text { Creates symbiotic } \\
\text { relationships between the } \\
\text { plants and the fish; it uses the } \\
\text { nutrient-rich waste from fish } \\
\text { tanks to "fertigate" } \\
\text { hydroponics production beds; } \\
\text { and hydroponic bed cleans } \\
\text { water for fish habitat. }\end{array}$ & \\
\hline
\end{tabular}

\subsubsection{Hydroponics}

Hydroponics is a method of growing food using mineral nutrient solutions in water without soil. Encyclopedia Britannica defines hydroponics as "the cultivation of plants in nutrient-enriched water, with or without the mechanical support of an inert medium such as sand or gravel" [27] (p. 8). The term is derived from the Greek words hydro and ponos, which translates to "water doing labor" or "water works". The use of water as a medium for crop growing is not totally new, but the commercial introduction of hydroponics arose only recently [28]. The National Aeronautics and Space Administration (NASA) researchers have seen hydroponics as a suitable method for growing food in outer space. They have been successful in producing vegetables such as onions, lettuce, and radishes. Overall, researchers have advanced the hydroponic method by making it more productive, reliable, and water-efficient.

Currently, the use of hydroponics in industrial agriculture has become widespread, providing several advantages over traditional soil-based cultivation. One of the primary advantages of this method is that it could eliminate or at least reduce soil-related cultivation problems (i.e., the insects, fungus, and bacteria that grow in soil) [28-30]. The hydroponic method is also relatively low-maintenance as well, insofar as weeding, tilling, kneeling and dirt removal are non-issues. The hydroponic method also provides a less labor-intensive way to manage larger areas of production $[8,31,32]$. Furthermore, it may offer a cleaner process given that no animal excreta are used. Furthermore, the hydroponic method provides an easier way to control nutrient levels and $\mathrm{pH}$ balance. According to Ebba Hedenblad and Marika Olsson, "In soil, many factors, such as temperature, oxygen level, moisture, and microorganisms, affect how soil-fixed nutrients are made accessible to plants since the nutrients are being dissolved in water through erosion and mineralization. Therefore, the hydroponic method may result in more uniform [produce] and better yields, as the optimum combination of nutrients can be provided to all plants" [30] (p. 17).

\subsubsection{Cylindrical Hydroponic Growing Systems}

The Volksgarden or cylindrical Omega Garden hydroponic growing system is a rotating-system technology where plants are placed inside rotary wheels. When wheels spin, plants rotate around centralized induction lights. The wheels rotate once every $50 \mathrm{~min}$ using a low-horsepower motor (it is possible to run the wheels via wind turbines and solar panels). In advanced rotary systems, the "plants rotate constantly and slowly around the light source, and their roots pass through a nutrient solution 
when they reach the bottom of the orbit. Turning at a constant rate allows the plants to take advantage of orbitotropism (based on the impact of gravity on growth) to grow bigger, stronger and faster" [32] (pp. 28-29). The Volksgarden system also provides a compact arrangement for the plants' roots in rock wool, thereby allowing the plants to grow more quickly than in traditional hydroponics [32].

Importantly, the "Ferris wheels", can multiply their capacity by adding "extreme verticality", i.e., unit stacking. To appreciate the efficiency of the system experts have noted, "Each cylinder holds 80 plants, and six cylinders are stacked together about 20 feet high at each station" [32] (p. 28). This adds up to 480 units per station requiring only $3.4 \mathrm{~m}^{2}\left(36 \mathrm{ft}^{2}\right)$ of space. Green Spirit Farms plans to fit 200 stations compactly in one of its vertical farms to grow 96,000 plants per year. For comparison, "conventional basil growers average 16,000 plants per acre $\left(43,560 \mathrm{ft}^{2}\right)$, less than $20 \%$ of the production Green Spirit Farms could have in just $7200 \mathrm{ft}^{2 "}$ [32] (p. 28). Furthermore, the Volksgarden system efficiently uses distilled water, requiring one-tenth the water used by traditional hydroponic systems. "Their distillation process allows multiple reuses of water. Rather than discarding the nutrient-dense liquid that remains after the produce has been harvested, it can be re-distilled and reused" [32] (p. 29). Furthermore, the Volksgarden system entails virtually no evaporation because the liquid reservoir for the growing system is closed. Additional water savings are provided by harnessing rainwater, collectively minimizing the demand on municipal water systems [32].

\subsubsection{Ultrasonic Foggers}

Scientists have designed ultrasonic fogger systems to minimize maintenance and maximize yield. They envision using them for myriad horticultural applications, including hydroponics, to provide multiple benefits such as [33]:

- Supplying upper roots with nutrient enriched fogs that penetrate deep into root tissues, keeping them moist, well-nourished, and free of decay [16].

- Promoting the growth of minuscule root hairs, which exponentially increase the root's ability to absorb water, nutrients, and exchange gases [32].

- Reducing the use of water and nutrients by up to $50 \%$ [32].

- Reducing the need for bulky and costly growing mediums [33].

- Efficiently using space, as the units are compact and designed to be fed by a remotely located reservoir [33].

- By integrating ultrasonic foggers, hydroponic systems come close to aeroponic systems [33].

However, there are some concerns that the hydroponic method relies heavily on chemicals whereby all of the nutrients supplied to the crop are dissolved in water [29]. A hydroponic system is based on chemical formulations to supply concentrations of mineral elements [30]. Liquid hydroponic systems utilize floating rafts and the Nutrient Film Technique (NFT), and they largely rely on non-circulating water culture- though, new recirculation systems can be applied in NFT techniques [30]. Further, some complain that the produce is tasteless because of all the added chemicals in the system and because the roots do not get adequate oxygen [30]. These shortcomings are partially addressed by the aeroponic method.

\subsubsection{Aeroponics}

Aeroponics is a technological leap forward from traditional hydroponics. An aeroponic system is defined as an enclosed air and water/nutrient ecosystem that fosters rapid plant growth with little water and direct sun and without soil or media [34]. The major difference between hydroponics and aeroponic systems is that the former uses water as the growing medium while the latter has no growing medium. Aeroponics uses mist or nutrient solutions instead of water, so it does not require containers or trays to hold water. It is an effective and efficient way of growing plants for it requires little water (requires 95 percent less water than traditional farming methods) and needs minimal space [34]. Plant boxes can be stacked up in almost any setting, even a basement or warehouse. 
The stacking arrangement of plant boxes is structured so that the top and bottom of the plants are suspended in the air, allowing the crown to grow upward and the roots downward freely. Plants are fed through a fine mist of nutrient-rich, water-mix solution. Because the system is enclosed, the nutrient mix is fully recycled, leading to significant water savings. This method, therefore, is particularly suitable in water-scarce regions. An additional advantage of the aeroponic method is that it is free of fertilizers or pesticides. Furthermore, research has revealed that this high-density planting method makes harvesting easier and provides higher yields. For example, one of the aeroponic experiments with tomato in Brooklyn, NY, resulted in quadrupling the crop over a year instead of the more common one or two crops [34].

\subsubsection{GrowCube}

Recent research and technological development take the aeroponics method to a higher level of productivity and efficiency. For example, GrowCube has proposed a new aeroponic prototype through the high-tech cube, which contains five light plastic plates that spin via a rotisserie-esque wheel and are lit by a strip of light-emitting diodes (LEDs) that provide the necessary light for photosynthesis [34]. At the top of the cube, a device sprays a nutrient-rich mist. The cube and its devices are controlled and managed via computer and software, and sensors inside the cube communicate with the computer to optimize the microclimate. The cube is also pressurized and equipped with an ultraviolet germicidal lamp and a high-efficiency particulate absorption (HEPA) filter, as well as "bug-killing filters in the pipes where the nutrient mixes are pumped" [34].

Consequently, the microclimate inside the cube is bug-free, making its produce free of pathogens. Remarkably, IT companies are developing special apps and food growing food recipes, increasingly available online. Consequently, the aeroponics system and the entire growing process can be optimized remotely [34]. "When it comes time to planting, simply stick your seeds in a growing medium ... and download the iOS app. From there, you can select and download a 'grow recipe' from the cloud ... Users are also encouraged to tweak and fork the recipes as they see fit, helping to improve the growing and to offer variations. So if you want crisper lettuce, you can select that as an option" [34]. Furthermore, by conducting the work autonomously, the computer-controlled environment reduces human errors and minimizes the effort of growing food [35].

With such a computerized system, almost anyone could become a sophisticated farmer. What is more, the computerized system will help to "engineer" taste and other characteristics producing crispy or spicy produce! GrowCube has managed to produce "herbs, flowers and foodstuffs like wheatgrass, microgreens, pea-shoots and even 28 heads of lettuce", and it plans to produce fruits such as grapes [34]. The prototype is costly and will likely benefit from economies of scale when it is produced in masses. Consequently, GrowCube plans to expand the project by producing hundreds of these high-tech cubes [34].

\subsubsection{Solar Aquaculture}

Solar aquaculture involves growing high-quality fish protein in small, clean, translucent, and controllable ponds that are exposed to sunlight. Microscopic green algae (nonflowering plants lacking a true stem, roots, and leaves) live in the pond with the fish and grow by absorbing nutrients from the water. In addition, sunlight that strikes the pond helps the algae to grow and causes the water to become warmer. Fish and algae grow faster in warmer water. This method could be suitable for vertical farms, enabling higher rates of production in limited spaces. A solar pond that is $1.5 \mathrm{~m}$ high, $1.5 \mathrm{~m}$ in diameter ( $5 \mathrm{ft}$ high, $5 \mathrm{ft}$ diameter) and contains $2649 \mathrm{~L}$ (700 gal) of water can produce an annual growth of $18 \mathrm{~kg}(40 \mathrm{lb})$ of fish [35].

In addition to supporting fish, solar ponds can serve indirectly as storage units for solar heat. Algae capture about five percent of the entered solar energy while water absorbs the rest (95\%). The pond makes air cooler during the day, given that much of the incoming sunlight is stored as warm water rather than hot air. In contrast, the pond warms the air at night as it releases heat. As such, 
heat from a solar pond can substitute for heating a greenhouse with gas, oil or wood or electricity, thereby saving on energy. However, the solar pond requires extensive maintenance because of the fish waste and some of the un-eaten food that transforms into waste. These problems are addressed by closed-loop systems and the aquaponics method.

\subsubsection{Aquaponics}

Aquaponics is a bio-system that integrates recirculated aquaculture (fish farming) with hydroponic vegetable, flower, and herb production to create symbiotic relationships between the plants and the fish. It achieves this symbiosis through using the nutrient-rich waste from fish tanks to "fertigate" hydroponic production beds. In turn, the hydroponic beds also function as bio-filters that remove gases, acids, and chemicals, such as ammonia, nitrates, and phosphates, from the water. Simultaneously, the gravel beds provide habitats for nitrifying bacteria, which augment the nutrient cycling and filter water. Consequently, the freshly cleansed water can be recirculated into the fish tanks. In one experimental project, aquaponics consisting of wetland pools containing perch and tilapia, whose waste provided nutrients for greens, solved the principal problems of both hydroponics and aquaculture as mentioned above [36] (Figure 2).

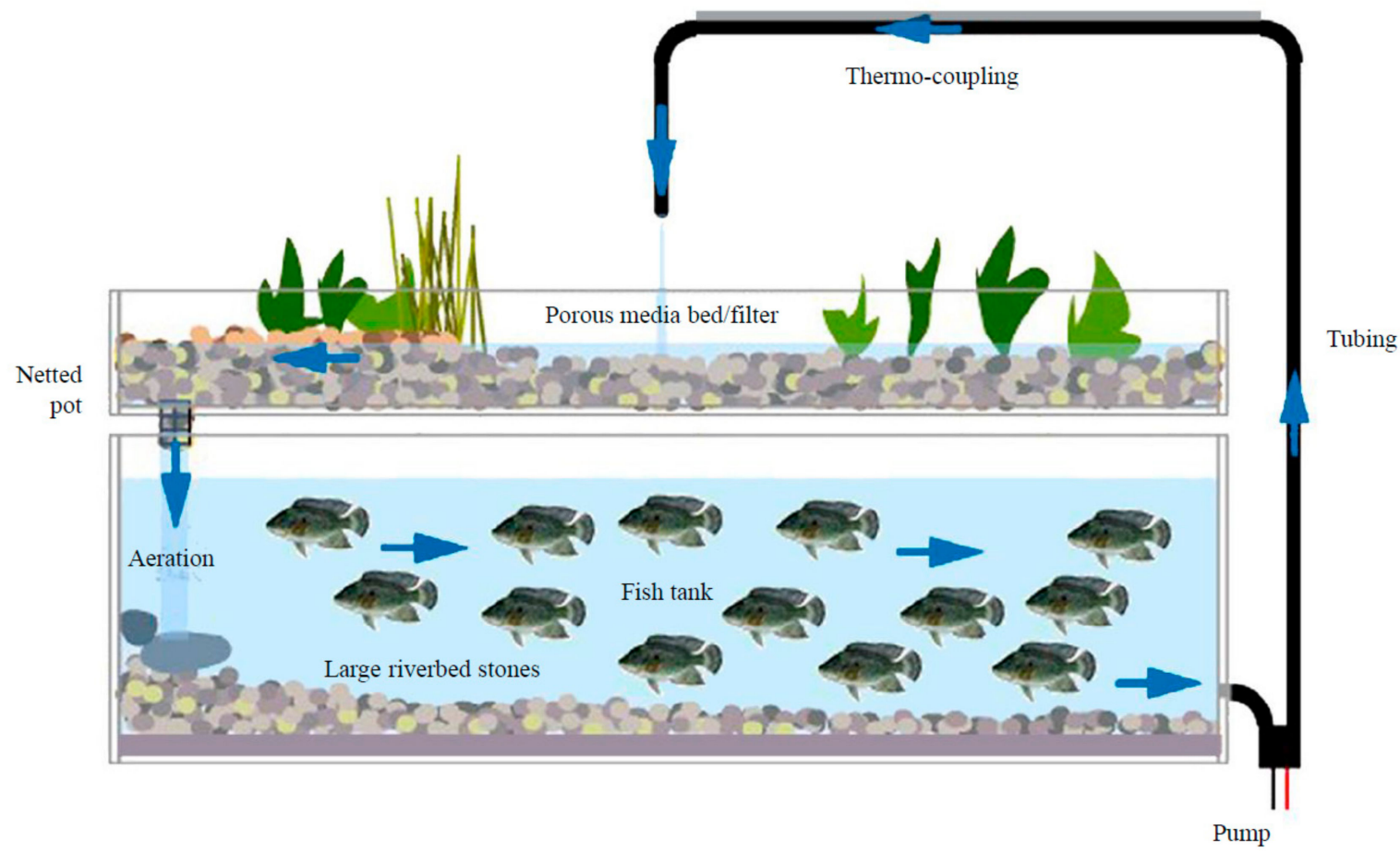

Figure 2. Basics of an aquaponic system (Adapted from [19]).

Researchers envision that the aquaponics system has the potential to become a model of sustainable food production by achieving the 3Rs (reduce, reuse, and recycle). It offers bountiful benefits, such as [36]:

- Cleaning water for the fish habitat;

- Providing organic liquid fertilizers that enable the healthy growth of plants;

- Providing efficiency since the waste products of one biological system serves as nutrients for a second biological system;

- Saving water since water is re-used through biological filtration and recirculation. This feature is attractive particularly in regions that lack water;

- Reducing, even eliminating, the need for chemicals and artificial fertilizers; 
- Resulting in a polyculture that increases biodiversity;

- Supplying locally-grown healthy food since the only fertility input is fish feed and all of the nutrients go through a biological process;

- Facilitating the creation of local jobs; and

- Creating an appealing business that supplies two unique products-fresh vegetables and fish—from one working unit.

Consequently, aquaponics is preferable to hydroponics. However, aquaponics systems continue to be at the experimental stage, having had limited commercialized success. This is because the technologies necessary to build aquaponics systems are relatively complex, requiring the mutual dependence of two different agricultural products. For this reason, aquaponics also requires intensive management [36].

\subsection{Lighting Technologies}

One of the important components of successful vertical farming is sound lighting. Available LED technologies provide only $28 \%$ efficiency, an efficiency rate that should be increased to about $50-60 \%$, at a minimum, to make indoor farming methods cost-effective [37]. Fortunately, experimental developments in LEDs have reached that mark [37,38]. Dutch lighting engineers at Philips have produced LEDs with $68 \%$ efficiency. Such an increase in lighting efficiency will dramatically cut costs. Also, a Dutch-based group called PlantLab has recently invented a lighting technology that could help to grow food on a small footprint. According to Michael Levenston, "This invention replaces sunlight with LEDs that produce the optimal wavelength of light for plant growth. Contrary to the sun, traditional assimilation lighting, and TL lighting LED only omits one color of light. No energy is wasted with light spectra that are not used ... by the plant" [38]. As such, the new lighting technology provides the correct lighting colors plants need for photosynthesis-blue, red, and infrared light.

Furthermore, new "induction" lighting technology simulates the color spectrum of sunlight to foster the growth of vegetables and fruits. "The light uses an electro-magnet to excite argon gas as its light source, instead of a filament. For this reason, [it] uses much less energy and can last up to 100,000 hours, twice as long as an LED light" [39]. It also generates more heat than LED light, but less than an incandescent bulb. Therefore, the lights create enough heat for growing plants without wasting energy to heat the entire building. Moreover, the light units are calibrated to create an "ideal" microenvironment by producing high-quality lighting that is similar to daylight. These units are also long lasting, with a life span of about one decade, and are sold at affordable prices.

\subsection{Farming Operation}

Researchers predict that farming operations will be fully automated in the near future. For example, monitoring systems will be widely implemented (in the form of sensors near each plant bed) to detect a plant's need for water, nutrients and other requirements for optimal growth and development. Sensors can also warn farmers by signaling the presence of harmful bacteria, viruses or other microorganism that cause disease. Also, a gas chromatograph technology will be able to analyze flavonoid levels accurately, providing the optimal time for harvesting. These specific technologies are not totally new. Their development has been on going and will likely proliferate in the near future [39].

\subsection{Farming from Afar}

One of the promising ideas under development is "farming from afar". The cell phone, its software and apps, will ultimately handle much of the day-to-day tending of crops, and vertical farmers will be able to manage multiple farms remotely. New apps will allow farm managers to adjust "nutrient levels and soil $\mathrm{pH}$ balance from a smartphone or tablet, and sound alarms if, say, a water pump fails on a vertical-growing system ... So if I'm over in London, where we're looking for a future vertical farm site to serve restaurants, I'll still be able to adjust the process in Michigan or Pennsylvania", 
as Paul Marks explained [40]. Farming from afar will drastically reduce operational costs by reducing labor and will provide considerable convenience, flexibility, and efficiency in managing farms. Further, by engaging new information technology and working with new online applications, farming could become an exciting and fun activity.

\section{5. "Closed-Loop Agricultural" Ecosystems}

"Closed-loop agricultural" ecosystems intend to mimic natural ecosystems that treat waste as a resource. Similar to aquaponics, the waste of one part of the system becomes the nutrients for the other. The closed-loop system recycles and reuses nearly every element of the farming process-dirty water, sewage, and nutrients. Food waste can also be converted to compost. In a closed-loop system, everything remains in the system, leading to a zero-waste outcome. This results not only in drastic decreases in waste but also in the creation of energy and other byproducts such as bedding and potting soil.

\section{Anaerobic Digester}

An anaerobic digester is a biogas recovery system that converts food waste into biogas to produce power and heat [41]. The Plant, a vertical farm in Chicago, has employed an anaerobic digester that captures the methane from 27 tons of daily food waste to produce electricity and heat. Figure 3 illustrates how The Plan has integrated an anaerobic digester in its employed close-loop system (also see Section 3.2 on The Plant). Similarly, Great Northern Hydroponics (GNH), in Quebec, Canada, has employed a cogeneration machine that reduces its heating costs and reliance on fossil fuels. GNH's power production has increased such that it is capable of selling electricity back to the Ontario Power Authority, decreasing the province's dependence on fossil fuels.

Main features of the closed-loop system:

- At the heart of the system is an anaerobic digester that turns organic materials into biogas, which is piped into turbine generator to make electricity for plant grow light.

- The plants make oxygen to the Kombucha tea brewery, and Kombucha tea brewery makes $\mathrm{CO}_{2}$ to the plant.

- Waste from the fish feeds the plants and the plants clean the water for the fish.

- More fish waste goes to the digester along with plants' waste, waste from outside sources and spent grain from the brewery.

- Spent barley from the brewery feeds the fish.

- Sludge from the digester that becomes algae duckweed also feeds the fish.

- Along electricity, the turbine makes steam which is piped to the commercial kitchen, brewery, and the entire building for heating and cooling.

- Therefore, the kitchen produces Kombucha tea, fresh vegetables, fish, beer, and food, all with no waste.

\subsection{Renewable Energy}

Some vertical farms have implemented, and others have proposed employing wind turbines and photovoltaic panels to supply power. Other systems, such as thermal systems that collect solar heat and warehouse refrigeration exhaust, are also under consideration.

\subsection{Integration within City Infrastructure}

Future proposals, for example by Plantagon, envision the integration of vertical farms with the city symbiotically. The proposal envisions that the vertical farm will collect organic waste, carbon dioxide, manure, $\mathrm{CO}_{2}$, and excess heat from plants and factories, and transform these into biogas for heating and cooling. In this way, the vertical farm not only could grow food but also help to develop sustainable solutions for better energy, heat, waste, and water use (Figure 4). 


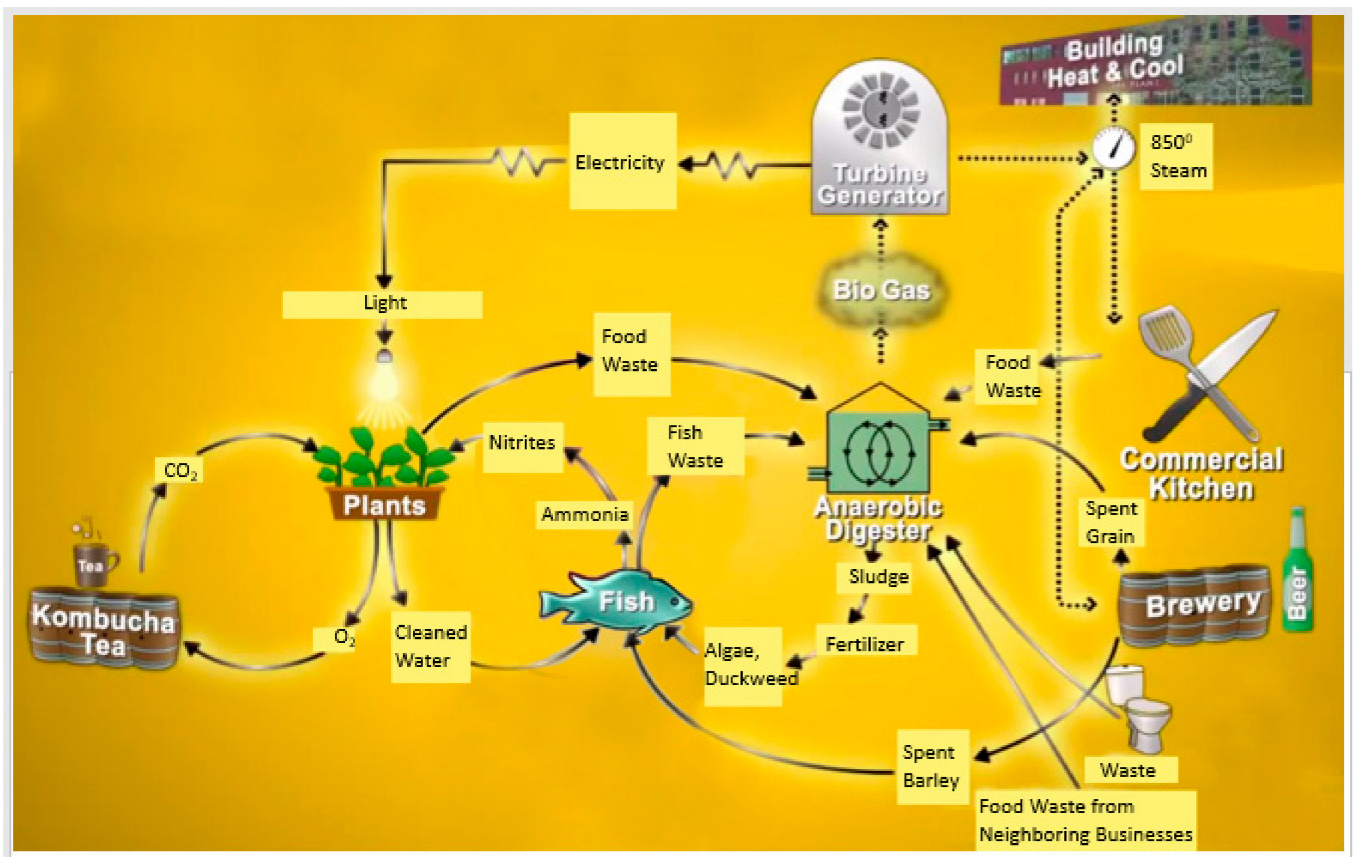

Figure 3. An illustration of an integrated food production through a closed-loop system (Adapted from [41]).

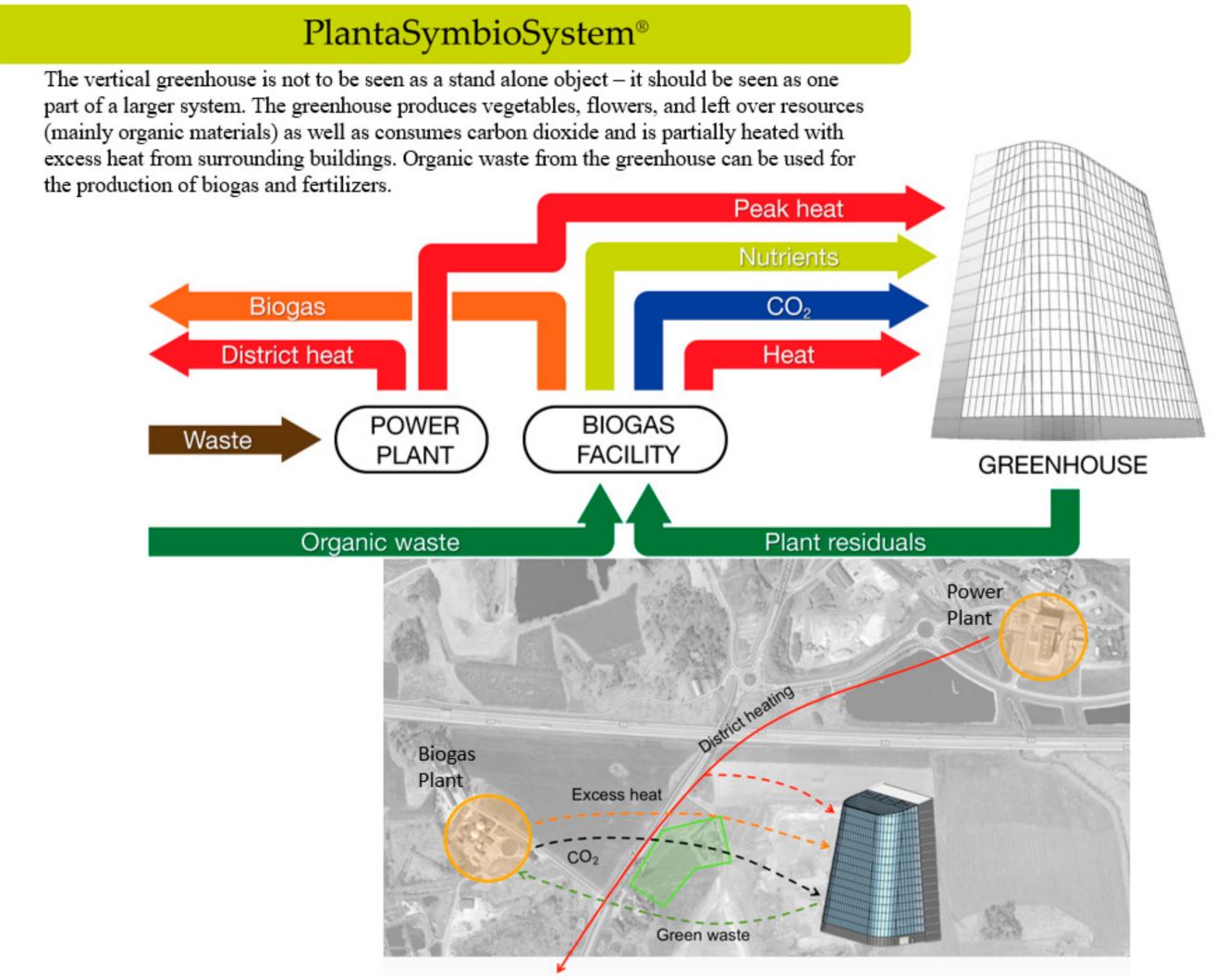

Figure 4. The proposed vertical farm in the downtown of Linköping, south of the capital Stockholm in Sweden by Plantagon provides an industrial symbiotic system. Partnership will be established between Plantagon, local energy company and local biogas plant. The greenhouse gets district heating from the power plant that runs through a major road, it gets excess heat and carbon dioxide from the biogas plant, and the leftover from the greenhouse goes into the biogas digestor. (Adapted from [42]). 


\subsection{Redefining Vertical Farms}

The aforementioned technologies are redefining the vertical farm as "a revolutionary approach to producing high quantities of nutritious and quality fresh food all year round, without relying on skilled labor, favorable weather, high soil fertility or high water usage" [24]. These new systems add advantages to vertical farming, summarized in Table 2.

Table 2. Advantages of high-tech vertical farming systems [42].

\begin{tabular}{|c|c|}
\hline 1. Reliable harvests & $\begin{array}{l}\text { Controlled indoor environments are independent of outside weather conditions and would provide } \\
\text { consistent and reliable growing cycles to meet delivery schedules and supply contracts. }\end{array}$ \\
\hline $\begin{array}{l}\text { 2. Minimum } \\
\text { overheads }\end{array}$ & Production overheads would decrease by $30 \%$. \\
\hline Low energy usage & $\begin{array}{l}\text { The use of high efficiency LED lighting technology ensures minimum power use for maximum plant } \\
\text { growth. Computer management of photosynthetic wavelengths, in harmony with phase of crop growth, } \\
\text { further minimizes energy use while ensuring optimized crop yields. }\end{array}$ \\
\hline Low labor costs & $\begin{array}{l}\text { Fully automated growing systems with automatic SMS text messaging would require manual labor only } \\
\text { for on-site planting, harvesting, and packaging. }\end{array}$ \\
\hline \multirow{2}{*}{$\begin{array}{l}\text { Low water usage } \\
\text { Reduced washing } \\
\text { and processing }\end{array}$} & Vertical farms would use around $10 \%$ of the water required for traditional open field farming. \\
\hline & Vertical farms would employ strict bio-security procedures to eliminate pests and diseases. \\
\hline Reduced transport costs & $\begin{array}{l}\text { Positioning of facilities close to the point of sale would dramatically decrease travel times, reducing } \\
\text { refrigeration, storage and transport costs in the process. }\end{array}$ \\
\hline $\begin{array}{l}\text { 3. Increased } \\
\text { growing areas }\end{array}$ & Vertical farms would supply nearly ten times more growing area than traditional farms. \\
\hline $\begin{array}{l}\text { 4. Maximum crop } \\
\text { yield }\end{array}$ & $\begin{array}{l}\text { Irrespective of external conditions, vertical farms can provide more crop rotations per year than open } \\
\text { field agriculture and other farming practices. Crop cycles are also faster due to controlled temperature, } \\
\text { humidity, light, etc. }\end{array}$ \\
\hline $\begin{array}{l}\text { 5. Wide range } \\
\text { of crops }\end{array}$ & The vertical farm would provide a wide range of crops. \\
\hline $\begin{array}{l}\text { 6. Fully integrated } \\
\text { technology }\end{array}$ & The vertical farm would be fully monitored, controlled, and automated. \\
\hline Optimum air quality & The temperature, $\mathrm{CO}_{2}$, and humidity levels of the vertical farm would be optimized at all times. \\
\hline $\begin{array}{l}\text { Optimum nutrient and } \\
\text { mineral quality }\end{array}$ & $\begin{array}{l}\text { The vertical farm would use specially formulated, biologically active nutrients in all crop cycles, } \\
\text { providing organic minerals and enzymes to ensure healthy plant growth. }\end{array}$ \\
\hline Optimum water quality & All fresh water's contaminants would be removed before entering the vertical farm. \\
\hline Optimum light quality & $\begin{array}{l}\text { High-intensity low-energy LED lighting would be specifically developed and used for maximum growth } \\
\text { rates, high reliability, and cost-effective operations. }\end{array}$ \\
\hline
\end{tabular}

\section{Vertical Farm Project Examples}

Several cities have embarked on vertical farming projects. The following narrative provides a concise summary, and Table 3 offers a list of these projects.

Table 3. Summary of examined projects.

\begin{tabular}{cccc}
\hline Vertical Farm & Location & Type & Status \\
\hline Nuvege & Kyoto, Japan & LR & Built \\
PlantLab & Den Bosch, Holland & LR & Built \\
Sky Greens & Singapore & LR & Built \\
Green Spirit Farms & New Buffalo, Michigan, USA & LR & Built \\
FarmedHere & Bedford Park, Illinois, USA & LR & Built \\
The Plant & Chicago, Illinois, USA & LR & Built \\
Green Girls Produce & Memphis, Tennessee, USA & LR & Built \\
Brooklyn Grange & Brooklyn, New York, USA & RT & Built \\
Gotham Greens & Brooklyn, New York, USA & RT & Built \\
Plantagon & Sweden & HR & Proposed \\
La Tour Vivante & France & HR & Proposed \\
Harvest Green Tower & Vancouver, Canada & HR & Proposed \\
Skyfarm & Toronto, Canada & HR & Proposed \\
Pyramid Farm & NA & HR & Proposed \\
TBD & Philippine & & \\
\hline
\end{tabular}

LR = Low Rise; HR = High Rise; RT = Rooftop. 


\subsection{Modest-Scale Vertical Farms}

Companies interested in modest-scale vertical farming are proliferating around the world. For example, Nuvege in Kyoto, Japan, is a $2787 \mathrm{~m}^{2}\left(30,000 \mathrm{ft}^{2}\right)$ hydroponic facility with $5295 \mathrm{~m}^{2}$ $\left(57,000 \mathrm{ft}^{2}\right)$ of vertical grow-space that produces a variety of lettuces in a safe environment from the nearby Fukushima nuclear plant [25]. PlantLab in Den Bosch, Holland, is a three-story underground vertical farm that uses advanced LED technology that calibrates light composition and intensity to precise needs, entirely removing the wavelengths of sunlight that prevent plant growth [25]. The farm employs an automated system that monitors and controls numerous variables including humidity, $\mathrm{CO}_{2}$, light intensity, light color, air velocity, irrigation, nutritional value, and air temperature [25]. The high-tech farm produces a yield three times the amount of the average greenhouse while reducing water use by $90 \%$.

\subsubsection{Sky Greens}

One of the promising vertical farms is the Sky Greens of Singapore. As a small island, but with a population of over five million, Singapore faces potential issues of food security. With land at a premium, limited space for farming is available. Singapore produces only $7 \%$ of the food it consumes, and only 250 acres of the island are devoted to farming. The remaining need is supplied by food imports from all over the world. However, the transportation costs of food are becoming increasingly prohibitive. For these reasons, Singapore has been taking vertical farming seriously. Although Singapore is an extreme case, it represents a looming problem facing myriad cities worldwide [26].

Sky Greens is Singapore's first commercial "tropical vegetable urban vertical farm ... to achieve enhanced green, sustainable production of safe, fresh and delicious vegetables, using minimal land, water, and energy resources" [43]. The five-year-old farm is 3-stories tall (9 m or $30 \mathrm{ft}$ ) and uses a method called "A-Go-Gro (AGG) Vertical Farming" that utilizes translucent green houses to grow tropical leafy vegetable year-round at significantly higher yields than traditional farming methods. Sky Greens is capable of producing one ton of fresh veggies every other day. It supplies a variety of tropical vegetables including Chinese cabbage, Spinach, Lettuce, Xiao Bai Cai, Bayam, Kang Kong, Cai Xin, Gai Lan and Nai Bai. By providing high-quality produce at relatively affordable costs, the farm has thrived and intends to expand its production, providing a wider variety of vegetables.

Structurally, the AGG system consists of tall aluminum A-frames that can be as high as $9 \mathrm{~m}$ $(30 \mathrm{ft})$ tall with 38 tiers of growing troughs that contain various growing media-soil and hydroponics. The A-frame system takes up only $5.6 \mathrm{~m}^{2}\left(60 \mathrm{ft}^{2}\right)$, making it ten times more efficient than conventional farming [43]. The troughs slowly rotate around the aluminum frame (about three rotations per day) to ensure that the plants obtain uniform sunlight. Such continuous exposure also reduces or even eliminates the need for artificial lighting in some areas of the building. Rotation is powered by a patented low carbon hydraulic system that contains trays of plants. The hydraulic system is an ancient technology empowered with a modern twist; it is a closed-loop that makes efficient use of gravity and consumes little energy. Each 9-m (30 ft) tower uses only $60 \mathrm{~W}$ of energy and, therefore, the owner spends only about " $\$ 360 /$ month ( $\$ 3 /$ tower) on electricity" to power the farm [43].

In addition to providing commercial benefits, Sky Greens is engaged in educational programs in the surrounding neighborhoods where students visit the farm, getting exposure and hands-on experience in transplanting, harvesting, and understanding the power of science and technology in creating green urban solutions. According to Sky Green's website, the project provides numerous economic and environmental benefits, summarized in Table 4. The project started as a prototype developed jointly with Agri-Food and the Veterinary Authority of Singapore (AVA) in 2010. Sky Greens together with AVA won the Minister for National Development's Research \& Development Award 2011 (Merit Award) for Vertical Farming. Sky Greens promises to become a viable food supplying option [43,44]. 
Table 4. The environmental and socioeconomic benefits of the Sky Greens vertical farm project [43].

\begin{tabular}{|c|c|}
\hline \multicolumn{2}{|r|}{ Environmental Benefits } \\
\hline $\begin{array}{l}\text { Environmentally } \\
\text { friendly and high-tech }\end{array}$ & $\begin{array}{l}\text { Sky Greens observes, learns and works with nature to achieve sustainability for the good of the } \\
\text { environment to grow safe, high-quality vegetables using green technologies. }\end{array}$ \\
\hline Low energy usage & $\begin{array}{l}\text { Outdoor green houses have abundant sunlight in the tropics. The A-Go-Gro system uses } \\
\text { patented low carbon hydraulic green technology to power the rotation of the tower at very low } \\
\text { energy costs, while still allowing the plants to receive abundant sunlight. }\end{array}$ \\
\hline Low water usage & $\begin{array}{l}\text { As the troughs of plants rotate, irrigation occurs using an innovative flooding method, using } \\
\text { very little water. Water is also recycled and reused. }\end{array}$ \\
\hline $\begin{array}{c}\text { Good waste \& } \\
\text { water management }\end{array}$ & $\begin{array}{l}\text { Sustainable water management practices are utilized with all organic wastes being composted } \\
\text { at the farm to ensure the use of safe, high-quality fertilizers. }\end{array}$ \\
\hline Green technologies & $\begin{array}{l}\text { Green technologies have been stringently implemented at the farm to achieve the three Rs } \\
\text { (reduce, reuse and recycle). }\end{array}$ \\
\hline \multicolumn{2}{|r|}{ Socioeconomic Benefits } \\
\hline Increased productivity & $\begin{array}{l}\text { The production yield of Sky Greens Farm is } 5 \text { to } 10 \text { times greater per unit of area than traditional } \\
\text { Singaporean farms that growing leafy vegetables in a conventional fashion. }\end{array}$ \\
\hline Tasty Vegetables & $\begin{array}{l}\text { Tropical leafy vegetables are grown in special soil-based media, which contribute to good } \\
\text { tasting vegetables, suitable for stir-fry and soups. The vegetables are harvested every day and } \\
\text { delivered almost immediately to retail outlets for consumers. }\end{array}$ \\
\hline Year-round production & $\begin{array}{l}\text { As the vertical farm structures are in protected-outdoor green houses, the vegetables are grown } \\
\text { in a controlled environment, protected from pests, winds and floods. }\end{array}$ \\
\hline $\begin{array}{l}\text { Consistent and } \\
\text { reliable harvest }\end{array}$ & $\begin{array}{c}\text { A steady supply of fresh leafy vegetables is assured as growing takes place in a } \\
\text { controlled environment. }\end{array}$ \\
\hline $\begin{array}{l}\text { Easy to install and easy } \\
\text { to maintain }\end{array}$ & The modular A-frame rotary system allows quick installation and easy maintenance. \\
\hline $\begin{array}{l}\text { Better ergonomics } \\
\text { \& automation }\end{array}$ & $\begin{array}{l}\text { The rotary system allows the troughs to be immediately adjusted for easy harvesting. } \\
\text { Automation increases the productivity of workers per ton of vegetables grown. }\end{array}$ \\
\hline Space savings & $\begin{array}{l}\text { The footprint of the vertical system is small but can produce significantly more per unit area } \\
\text { than traditional farms. It can also be customized to suit different crop requirements and } \\
\text { varying environments. }\end{array}$ \\
\hline
\end{tabular}

In the United States, cities such as New York, Chicago, Milwaukee, and others are becoming pioneers of vertical farming by repurposing vacant urban warehouses, derelict buildings and high-rises to grow food. With so much vacant space available, the cost of property is often affordable to buy or rent. Within the buildings, vertical farmers build tall structures with several levels of growing beds, often lined with artificial lights, to grow crops and "microgreens", i.e., salad vegetables such as arugula, Swiss chard, mustard, beetroot, and sunflowers. Indoor vertical farming is playing an important role in spurring economic development by repurposing vacant industrial buildings, supplying fresh and healthy food and providing jobs in distressed areas. Among the pioneering vertical farm projects to spread across the U.S. are those carried by companies such as Green Spirit Farms, FarmedHere, The Plant, and Green Girls.

\subsubsection{Green Spirit Farms}

Located in New Buffalo, Michigan, Green Spirit Farms (GSF) is a professional food company that has openly embraced vertical farming. The New Buffalo facility has grown out of a former plastic factory. The building contains about $3716 \mathrm{~m}^{2}\left(40,000 \mathrm{ft}^{2}\right)$ of space and sits on an 11-ha (27-ac) site. As standard practice, GSF will enter older vacant industrial or commercial buildings to supply produce nearby urban markets. It aims to provide local markets with high quality, fresh, pesticide-free, non-genetically modified organism (GMO) foods at affordable prices. The company chooses to grow products with a high local demand like lettuce, basil, spinach, kale, arugula, peppers, tomatoes, stevia, strawberries, and Brussel sprouts. It sells its produce locally to grocery stores and restaurants and to a host of small "Harvest Markets" which sells directly to consumers. GSF runs vertical organic farms in Atlanta, Philadelphia, Canada, and the United Kingdom [45]. The company has a strong belief in 
vertical farming. According to Green Spirit Farms' Research and Development Manager Daniel Kluko, the future of farming is heading in one clear direction: the vertical. "If we want to feed hungry people this is how we need to farm ... We cut out the risk of traditional farming, the labor, and most of the equipment costs ... This is not a niche business, it's not something novel, this is a necessity for the human race to continue to live" [46].

GSF has advanced several technologies to grow vegetables. These include the Volksgarden Rotary Garden unit, referred to as a Rotary Vertical Growing Station (RVGS), and a multi-level tray system, referred to as a Vertical Growing Station (VGS). GSF has lately commercialized rotary and vertical farming systems using patented techniques to grow local vegetables, herbs, and some fruits, and has opened vertical farms in repurposed industrial buildings, including one in East Benton, Pennsylvania. The new facility constitutes a major expansion compared to GSF's first facility in New Buffalo, Michigan, containing 1715 vertical growing stations that will produce herbs, leafy vegetables, peppers and tomatoes, the equivalent of 81 ha $(200 \mathrm{ac})$ of farmland harvested year-round. This is enabled by facility's efficiency, which uses "98 percent less water, 96 percent less land, and 40 percent less energy" than would be required by traditional agriculture [46]. It is expected that the facility will create over 100 jobs to support the local economy. GSF has invested about $\$ 27$ million to establish the vertical farm and received financial aid including a \$300,000 Pennsylvania First Program grant, \$303,000 in Job Creation Tax Credits, and a \$45,450 Guaranteed Free Training grant to train new employees [47]. The location has appealed to Green Spirit because of its proximity to large local markets, with most of its produce selling within approximately 75 miles of the farm [47]. In summary, the vertical farm project provides a useful example of adaptive reuse established through a strong public-private partnership. This has been made possible through the collaboration between GSF and several agencies including the Commonwealth of Pennsylvania, Lackawanna County, Benton Township, and the Greater Scranton Chamber of Commerce.

\subsubsection{FarmedHere}

FarmedHere is a company that was founded in 2011 and has recently expanded to three locations in Illinois: Englewood, a Chicago Southside neighborhood; Flanagan in downstate Illinois; and recently in Bedford Park, a Southwest Chicago suburb. As the company grows, it expects to supply $6 \%$ or more of the Chicago area's demand for premium green and culinary herbs. The company also hires local youths through Windy City Harvest, a Chicago Botanic Garden-led urban agriculture-training program targeted to underserved youths. FarmedHere received the USDA (the U.S. Department of Agriculture) Organic Certification at the end of 2012 [48]. The company's product is spreading in several grocery stores including Whole Foods, Chicago-area Mariano's Fresh Market, Green Grocer, and possibly soon at Trader Joe's and Meijer. FarmedHere was able to receive financial support from Good Food and Whole Foods, the farm's largest customers. The company expects that it has a market niche given the recent generational demands for healthy and organic foods. These new businesses also expect to obtain subsidies from tax-increment financing as well as property-tax breaks for reviving industrial properties [48].

Bedford Park's facility is about $8361 \mathrm{~m}^{2}\left(90,000 \mathrm{ft}^{2}\right)$, much larger than both the first facility in Englewood $\left(371 \mathrm{~m}^{2}\left(4000 \mathrm{ft}^{2}\right)\right)$ and the second facility in Flanagan $\left(929 \mathrm{~m}^{2}\left(10,000 \mathrm{ft}^{2}\right)\right)$. Bedford Park's facility, about $24 \mathrm{~km}(15 \mathrm{mi})$ from downtown Chicago, is now hyped as the first of its kind and the largest indoor vertical farm in America [48]. It was opened in 2013 and is expected to become a new model for growing produce efficiently in a high tech manner. The farm resides in a two-story, windowless warehouse, and is designed to occupy the full extent of the space. Currently, the farm consists of two structures with large growing beds lit by fluorescent lighting. The first structure contains the aquaponics system where water circulates between fish tanks, feeding plants that rest in cutouts on Styrofoam "floats" above. The second structure contains the aeroponics system, with water misters underneath that spray the exposed roots of the plants. Workers plant the seeds and grow seedlings on racks that then are transferred into the growing systems. After about a month, the crops 
are harvested and packaged manually in a cooling room at the facility, and then shipped the next morning to grocers in Chicago's metropolitan area [49].

By stacking aquaponics and aeroponics systems vertically, the facility contains $13,935 \mathrm{~m}^{2}$ $\left(150,000 \mathrm{ft}^{2}\right)$ of growing space, or about 1.4 ha $(3.5 \mathrm{ac})$. Planting in a controlled environment with ideal humidity and temperature ensures optimal growth. FarmedHere produces about 136,078 kg $(300,000 \mathrm{lb})$ of leafy greens and plans to grow to what will eventually amount to more than $453,592 \mathrm{~kg}$ (a million pounds) of chemical, herbicide and pesticide-free leafy greens yearly [49]. It also plans to expand by producing peppers, tomatoes, and other popular vegetables. Their aquaponics produces fish and organic herbs-basil and the like-while their aeroponics produces leafy greens like arugula and watercress. For space efficiency, plants are grown on six shelves that receive artificial fluorescent lighting and that are attended by workers using scissor lifts. The aquaponics method filters the nitrogen-rich waste of the tilapia fish and uses it to feed plants, and the hormone-free tilapia are bred in four 3028-L (800-gal) tanks, where water is ultimately recycled to create a closed loop that reduces water use by $97 \%$. Therefore, the system is efficient in its use of water and space.

These new facilities also provide "on-demand farming" meaning they are flexible and responsive to market demands. For example, demand may suddenly increase for particular types of mixed greens or mini greens. "We could change the whole system ... and pretty much within the next 14 to 28 days, we [would] have a full grown plant, whatever the market requires" [50]. However, the prime obstacle these farms face remains the electricity needed to grow the plants and heat the space. Because of exorbitant energy bills, some indoor farms have been closed down. Dickson Despommier, in his book "The Vertical Farm: Feeding the World in the 21st Century", stresses the fact that energy remains the primary hurdle [4]. Nevertheless, vertical farmers are trying to find solutions by exploring solar, wind and methane gas as ways to generate electricity, or by supplementing artificial light with natural light through windows and skylights. Other farmers are experimenting with flickering lights sufficient to grow plants with little power.

\subsection{The Plant}

Located in the heart of Chicago's derelict stockyards, the almost century old site of The Plant has a long history of food production as a former meatpacking facility and the former home of Peer Foods. The four-story, $8686 \mathrm{~m}^{2}\left(93,500 \mathrm{ft}^{2}\right)$ red brick warehouse is now set to become a major net zero vertical farm where the operation is fueled by food waste [51]. The zero-energy facility relies on an on-site Combined Heating and Power (CHP) system that contains a large anaerobic digester that converts food waste into biogas to power, heat and cool the building. The anaerobic digester captures the methane from 27 tons of food waste daily and 11,000 annually and burns it to produce electricity and heat. The Plant plans to turn the facility into a food business incubator, research lab and educational and training facility for vertical farming. The building's transformation, which started in 2010, was completed in 2016 [51].

The Plant is currently producing greens, mushrooms, bread, and Kombucha tea. Eventually, the facility will combine a tilapia farm, beer brewery, Kombucha brewery, communal kitchen, an aquaponics system, and green energy production. "We're working to show what truly sustainable food production and economic development looks like by farming inside an old meatpacking facility, incubating small craft food businesses, brewing beer and kombucha, and doing it all using only renewable energy that we make onsite. By connecting outputs of one business to the inputs of another, we are harnessing value from materials that most people would throw away" [51]. The conversion of the space into a vertical farm and food business incubator was partly made possible by a $\$ 1.5$ million grant from the Illinois Department of Commerce and Economic Opportunity (DCEO) to support the development of a comprehensive renewable energy system [51]. 


\subsection{Green Girls}

Green Girls Produce, a professional food company, is Tennessee's first indoor vertical farm that supplies local restaurants with a year-round fresh produce in an effort to improve the health of Memphians and to fight urban blight. The 60,000- $\mathrm{ft}^{2}$ facility is located in Memphis' Historic Downtown on the 4th floor of the Emerge Building. Restaurants have a desire for microgreens, which give meals an additional flavoring and pizzazz [52]. "Chefs love them because they make a boring dish pop, they add intense flavor, texture and vivid color ... On top of that, they are nutritious with up to 40 times the nutrients and vitamins of their mature counterparts" [52]. However, restaurants often refrain from purchasing microgreens given their high costs. Restaurants typically pay about $\$ 100$ a pound for microgreens. The vertical farm reduces the costs down to below $\$ 40$ per pound. Green Girls estimates a revenue of about one million dollars a year. It supplies affordable microgreens and makes a profit because of efficient technologies provided by automated, re-circulating hydroponic systems that require only two employees to run. It is characterized by being clean, efficient in its water use (Green Girls uses 90\% less water than conventional farming) and green in its energy use, employing only LED lighting [52].

\subsection{Rooftop Farming}

Rooftop farming simply involves the growing of fruits and vegetable on a rooftop. With a dearth of suitable urban farming land, roofs are increasingly being seen as a plausible space for growing food and a proactive measure in building a sustainable future for cities. Indeed, an abundance of unused rooftop spaces prevails. For example, Honolulu's buildings alone contain more than 1,579,351 $\mathrm{m}^{2}$ $\left(17,000,000 \mathrm{ft}^{2}\right)$ of rooftops. Consequently, in recent years, a great number of rooftop farms have sprung up and some green roofs have been transformed into rooftop farms [53-55].

Overall, converting green roofs into rooftop gardens is a rising trend that aims to "scale up" urban agriculture. Similar to green roofs, rooftop farms are viewed as a necessity for combatting the heat-island effect, to mitigate stormwater runoff and to insulate buildings. In addition to these environmental benefits, rooftop farming provides the benefits of supplying the community with fresh produce and promoting modest-scale urban agriculture as well as providing tangible connections to food, See Table 5. Among the common vegetables grown on rooftops are kale, collard greens, carrots, radishes, peppers, beans, beets, cherry tomatoes, and various herbs [56]. Though, it should be noted that a slight distinction between a vertical garden and a vertical farm exists. While both grow plants vertically, the former not always produces fruits and vegetable, and the latter does that exclusively. Vertical farms usually occupy larger areas than that by vertical gardens. Nevertheless, the produce of both types (vertical gardens and vertical farms) is offered to local communities, stores, and restaurants.

Rooftop farming is not a wholly original idea given that its history goes back to the ziggurats of ancient Mesopotamia and the Hanging Gardens of Babylon. To this day, however, continuing challenges in implementing rooftop farms persist. The structure must be strong enough to support the heavy weight of soil and greenhouse structures. Usually, the edges of rooftops are suitable to support moderate loads, but the central areas may need extra reinforcement [57].

Furthermore, a rooftop requires building access, which imposes logistical issues, liability, weather conditions, and insurance risks. Zoning codes could also be obstacles to obtaining permits. For these reasons, urban farmers are struggling to create efficient farming systems while making a profit. Balancing costs and profits indicates that not every green roof is well suited for farming. For example, in 2012 Local Garden, a rooftop farm that was opened in Vancouver, Canada, was recently closed due to economic reasons. Overall, rooftop farming is still a work in progress, but it has great potential as an urban farming system [58]. 
Table 5. Summary of the benefits of rooftop farms [53].

\begin{tabular}{|c|c|}
\hline \multicolumn{2}{|r|}{ Environmental Benefits } \\
\hline $\begin{array}{c}\text { Energy } \\
\text { Conservation }\end{array}$ & $\begin{array}{l}\text { The use of green roofs compared to conventional roofing surfaces significantly affects the energy } \\
\text { balance within a building. Studies have revealed that green roofs have the potential to reduce a } \\
\text { building's energy use by as much as } 30 \% \text {. }\end{array}$ \\
\hline $\begin{array}{l}\text { Stormwater } \\
\text { Management }\end{array}$ & $\begin{array}{l}\text { A green roof absorbs rainwater and helps to prevent sewer system back-ups and contaminated } \\
\text { stormwater overflow. Green roofs can also help to prevent catastrophic environmental events, } \\
\text { such as the Ala Wai Canal sewage spill disaster. }\end{array}$ \\
\hline $\begin{array}{l}\text { Fossil Fuel } \\
\text { Reduction }\end{array}$ & $\begin{array}{l}\text { A rooftop farm can grow hyper-local foods. Growing Low Food Mile organic produce substantially } \\
\text { reduces the fossil fuel consumption associated with the traditional food transportation system. }\end{array}$ \\
\hline Global Warming & $\begin{array}{l}\text { Green roofs sequester carbon from the atmosphere, lower the levels of carbon dioxide in the air, } \\
\text { eliminate the build-up of greenhouse gases, and keep city temperatures cooler by effectively } \\
\text { reducing the "Urban Heat Island Effect". }\end{array}$ \\
\hline Biodiversity & $\begin{array}{l}\text { By replacing inorganic, lifeless roofs with living and thriving green spaces, green roofs support } \\
\text { increased biodiversity in urban environments-offering a habitat for a multitude of } \\
\text { organisms-from birds to butterflies to countless other beneficial insects. }\end{array}$ \\
\hline $\begin{array}{l}\text { Environmental } \\
\text { Stewardship }\end{array}$ & $\begin{array}{l}\text { Organic rooftop farming protects soil and water from toxic pesticides, herbicides, fungicides, } \\
\text { and other dangerous chemicals typically used in conventional farming. }\end{array}$ \\
\hline \multicolumn{2}{|r|}{ Socioeconomic Benefits } \\
\hline Community & $\begin{array}{l}\text { A rooftop farm is a beacon of sustainable community building that creates tangible connections } \\
\text { between farmers and consumers. Rooftop farms have the power to do this throughout the city, } \\
\text { no matter how scarce or valuable the land. }\end{array}$ \\
\hline $\begin{array}{l}\text { Local Food } \\
\text { Economy }\end{array}$ & $\begin{array}{l}\text { Rooftop farms generate revenue for local farmers and businesses. In this way, rooftop agriculture } \\
\text { can also be viewed as an emerging green technology that creates jobs and improves food } \\
\text { self-sufficiency by providing organic and Hyper-Local produce. }\end{array}$ \\
\hline $\begin{array}{l}\text { Nutrition and } \\
\text { health }\end{array}$ & $\begin{array}{l}\text { As an example, the produce of FarmRoof }{ }^{\mathrm{TM}} \text { is extraordinarily nutritious and healthy. Thanks to a } \\
\text { special soil that has been infused with minerals, trace elements, omegas, proteins and } \\
\text { microorganisms, all of their crops are packed with enzymes, antioxidants, nutrients, and minerals. }\end{array}$ \\
\hline $\begin{array}{l}\text { Aesthetics and } \\
\text { Beauty }\end{array}$ & $\begin{array}{l}\text { Supplanting inorganic, lifeless roofs with vibrant greenery, green roofs can beautify cityscapes and } \\
\text { balance an otherwise bleak horizon of concrete and tar. }\end{array}$ \\
\hline
\end{tabular}

\subsubsection{Brooklyn Grange}

Several rooftop farms have recently sprung up in New York City, the largest of which is Brooklyn Grange rooftop farm-about one acre in size-and is claimed to be the world's largest rooftop garden [59]. Placed on top of a six-story warehouse that was built in 1919, Brooklyn Garage grows a wide-range of "organic produce that includes 40 varieties of tomatoes, peppers, fennel, salad greens, kale, Swiss chard, beans and a variety of delicious root vegetables such as beets, carrots, and radishes, as well as herbs" [42]. Their produce is grown in $19 \mathrm{~cm}$ (7.5 in) deep beds with Rooflite soil [59,60]. "Rooflite is a lightweight soil composed of organic matter compost and small porous stones which break down to add trace minerals that are needed for the produce to grow into a healthy and mature state" [60]. Brooklyn Grange is thriving and plans to expand its operation [61].

\subsubsection{Gotham Greens}

Gotham Greens is a $1394 \mathrm{~m}^{2}\left(15,000 \mathrm{ft}^{2}\right)$ facility atop a two-story building in Greenpoint, Brooklyn, New York. Constructed in 2011, it is claimed to be the first rooftop hydroponic commercial farm that uses technologically sophisticated Controlled Environment Agriculture (CEA) in an urban setting in the United States. The facility enjoys unusual farming efficiencies given that it uses less square footage to grow 7-8 times more food than traditional farming, providing produce year-round that is pesticide free [62,63]. Gotham Greens offers the advantage of growing summer vegetables in the winter, enhancing New York City's barren landscape at this time, and plans to produce 80-100 tons of pesticide-free, premium-quality lettuce, salad greens, and herbs yearly. Gotham Greens is not only aiming to provide quality produce but also to save on energy by employing advanced computer systems that control heating, cooling, irrigation and plant nutrition, while utilizing on-site solar 
photovoltaics. Energy use is reduced further by providing natural ventilation, double-glazing, and thermal insulation that is supplied by the rooftop farm and through high-efficiency pumps and fans. As such, the facility optimizes energy use and consumes less land and water than that of a conventional farm. These energy-saving measures are particularly suitable for New York City given its rapid increase in energy costs. Because of these energy saving innovations, Gotham Greens will likely be able to reduce its production costs significantly [45,46]. Interestingly, Gotham Greens was the only fresh food supplier in New York during the Sandy Hurricane. This highlights the benefits of protected agriculture in urban areas-particularly as we face climate change-while open-air agriculture can suffer from weather damages [64].

\subsection{Multi-Story Farms}

As mentioned earlier, there have been an increasing number of proposals for multi-story farms that remain ideas on the drawing board. This is due, in large part, to the fact that these ideas are not yet economically feasible. However, some companies have taken this endeavor seriously and are on the verge of implementing some of these visionary ideas. Among the pioneering companies is Plantagon.

\subsubsection{Plantagon}

Founded in 2008 in Stockholm and headed by Hans Hassle, Plantagon is a Swedish vertical agriculture company that has flourished through the establishment of offices in cities around the world, including Shanghai, China, and Singapore. Plantagon collaborates with other companies such as SymbioCity and SWECO that are also devoted to finding new methods of vertical farming and in clean technologies (Figure 5). It has also established research ties with academic institutions such as Linköping University in Linköping, Sweden, Nanyang Technological University in Singapore, and Tongji University in Shanghai, China. The company participated in Shanghai's World Expo 2010 and won the Globe Sustainability Innovation Award that same year. It also won a Silver Stevie Award for being Europe's "most innovative company" in 2012 [65].

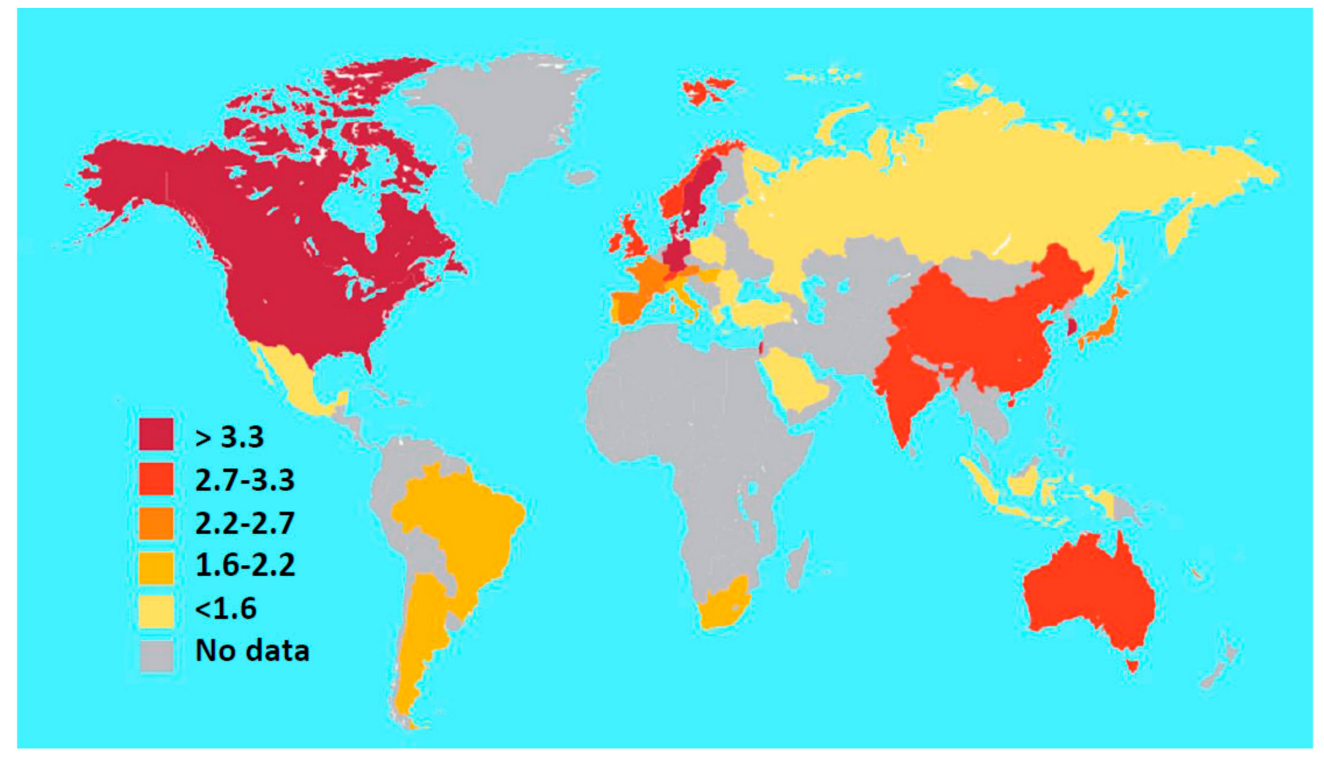

Figure 5. Map of global cleantech innovation ranking (on a scale from 1 to 5 , with 5 being the highest score). (Adapted from [65]).

\subsubsection{Organizational Structure}

Plantagon has embraced an innovative organizational structure, which they call "companization", that combines two legally bound units, a profit-driven company called Plantagon International AB, 
and a non-profit association called Plantagon Non-profit Association [65]. This "companization" aims to unite profit-driven comercial forces with nonprofit organizational values [66]. It is a blend between the top-down action oriented commercial organization and the bottom-up inclusive and democratic nonprofit association. The two units of the company are dependent upon one another, thereby making it difficult for the company to act irresponsibly and unethically. Plantagon is also tied to overarching ethical frameworks provided by the "UN Global Compact" and the "Earth Charter" in their articles of association and statutes. Their board members, from both the profit and nonprofit units, constantly co-review financial and social performance, bringing "moral questions to the otherwise purely economic forum $[65,66]$ (Figure 6).

\subsubsection{Technical Innovations}

The company is not only innovative in its organizational structure but also in its technology. The company has invented an automated growing food process through a helical structure that would be placed in the center of a building. This structure employs an efficient robotic belt that moves each row of plants one by one rather altogether. At the ground level, workers place seeds in pots and then lifts elevate them to the top of the helix. Here, automatically they are placed on a belt that takes them steadily back down to the ground, controlling the amount of sunlight they receive depending on their age and size. By the time they reach the ground, the plants are ready to be harvested. To keep the crops in sunlight as much as possible, the trays move more quickly when in the shade. Eventually, LED-lights will be employed to complement solar exposure (Figure 7). Plantagon has also made advancements in hydroponics by introducing pumice soil as a growing medium instead of relying completely on water. Pumice, a volcanic rock that results from the cooling of lava in water, possesses a unique porosity that absorbs nutrients and then channels them to plants. This may overcome the common problem of tastelessness that hydroponically generated produce is notorious for, though both methods provide similar levels of nutrition [66].

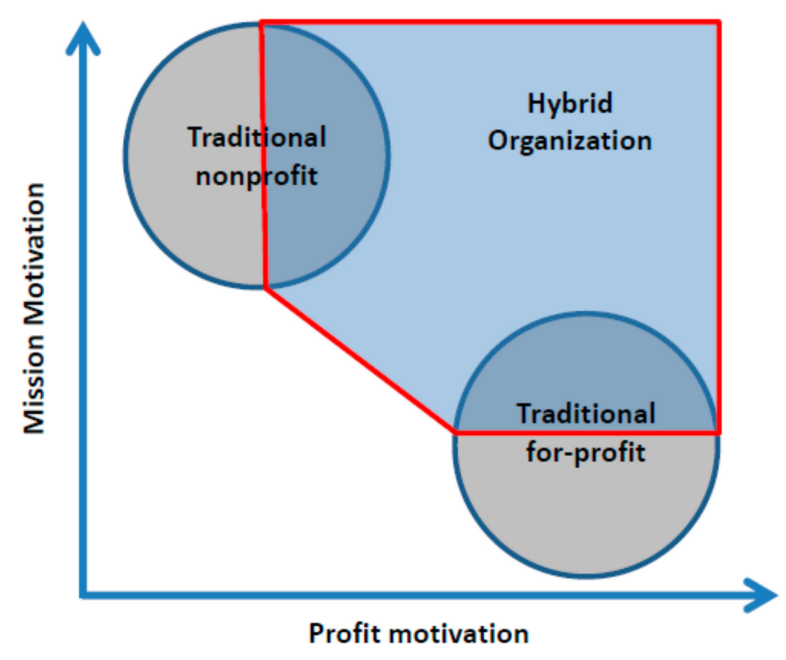

Figure 6. The concept of "companization" by Plantagon. The model is described as a hybrid system that combines two legally bound units: one of the units is a profit-driven company called Plantagon International AB, and the other one is non-profitable association called Plantagon Non-profit Association [65]. The "companization" aims to combine profit-driven commercial forces with non-profit moral and ethically-oriented driving forces in one organization [65]. It is a blend between the top-down action oriented commercial organization and the bottom-up, inclusive and democratic nonprofit association. (Adapted from [65]). 


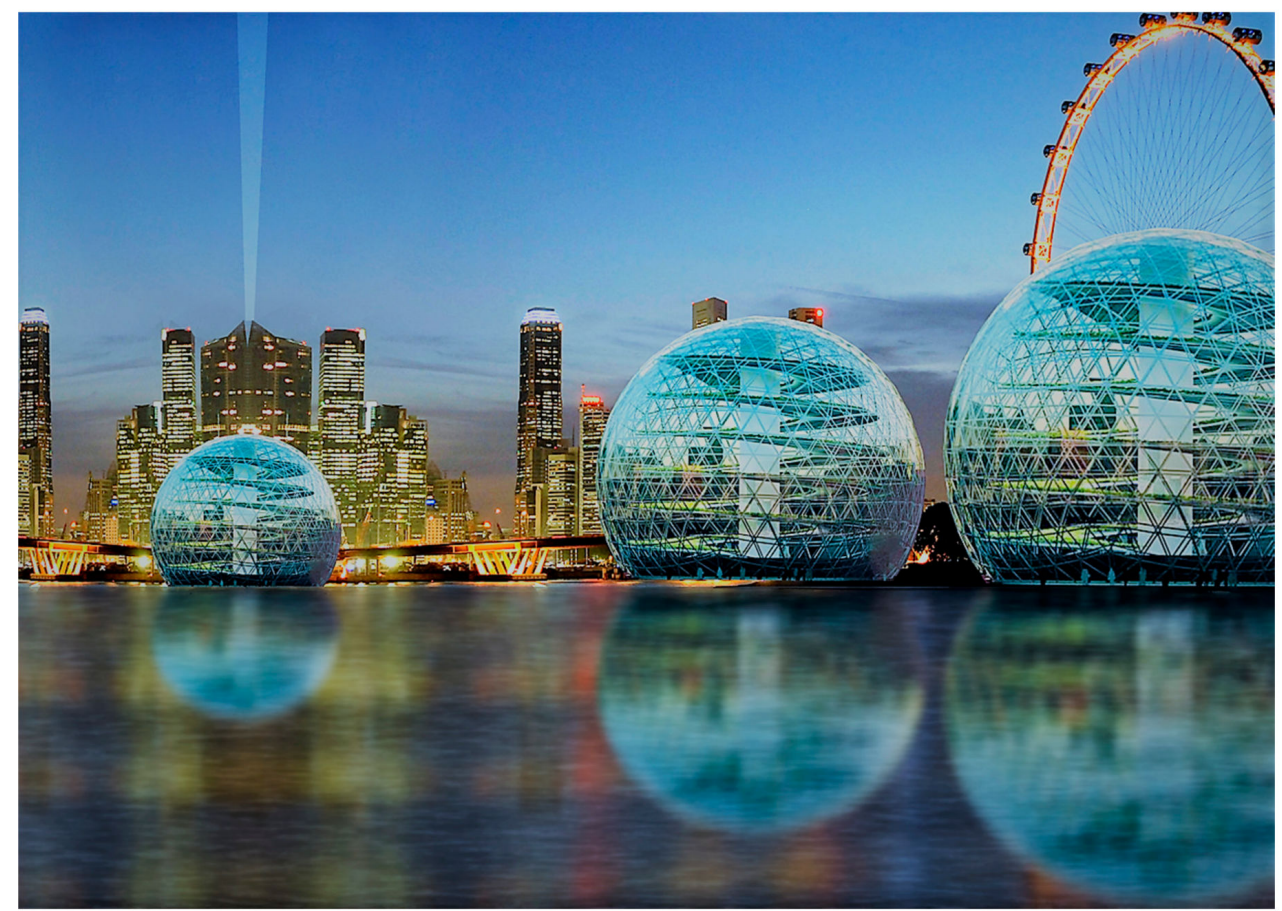

Figure 7. A proposed vertical farm by Plantagon. It comprises a helix structure placed in the center of a sphere-shape building and stretches vertically. The helix structure contains a robot belt that instead of moving thousands of plants over the whole belt, it moves each raw of plants one by one. Seeds are placed in pots on the belt at the ground floor level. Then, plants are elevated to the top by an elevator and placed on the moving belt which takes them back to the ground, and by the time they reach the ground floor, plants are ready to harvest. (Drawing by author).

Plantagon offers three approaches to vertical farming: façade farming, multifunctional farming, and standalone farming [65].

The Plantawall Façade System

This approach proposes turning a building's façade into a productive greenhouse. It specifically suggests placing a six-meter-deep $(20 \mathrm{ft})$ greenhouse at the perimeter where solar exposure is greatest. Plants sit in trays that constantly move on parallel conveyor belts, obtaining maximum exposure to natural light in the process. The PlantaWall façade system is based on a flexible modular structure that can be attached to the whole facade or part of an existing structure. In addition to structural flexibility, the façade system provides the benefit of soundproofing, supporting a healthy work environment, and improving thermal insulation and shade. Furthermore, the system fosters a symbiotic relationship that creates a healthy environment for everyone by transferring $\mathrm{CO}_{2}$ from people to plants and $\mathrm{O}_{2}$ from plants to people. However, the façade system reduces the amount of natural light that can penetrate deeply into a space [65].

\section{Multi-Functional}

In addition to farming, the multifunctional vertical farm incorporates functions such as office space, hotel, and retail space as well as residential and educational uses.

\section{Standalone}

The standalone vertical farm is dedicated exclusively to the industrial production of food. The company has produced two prototypes, a sphere for tropical climates and a half-moon shape for temperate climates. The later prototype, named "Plantscraper" is a building that has been proposed 
in downtown Linköping, south of the Swedish capital of Stockholm (Figure 8). The purpose of this structure has been to create a reference building that can be used as a model of vertical farming. The "Plantscraper" is a 12-story, mixed-used tower that houses an indoor farm along the southern façade (The PlantaWall), a farmers market at the ground floor and office spaces for proposed urban farming research [65]. The renting of office space will provide supplemental income to the building. It is estimated that the Plantscraper will produce between 300 and 500 metric tons of leafy greens, particularly pak choi, a year. Pak choi, also known as celery cabbage, is a Chinese vegetable that can be eaten raw or cooked [65]. This leafy green has been emphasized because Plantagon wants to use this building as a model for Asian cities. In addition, the building will collect and reuse all wastewater, with all pesticides, fertilizers, and soil pollution being automatically monitored and controlled. Interestingly, Plantagon plans to integrate the vertical farm with the city's civic infrastructure, i.e., electricity, gas, water, and sewage [66].

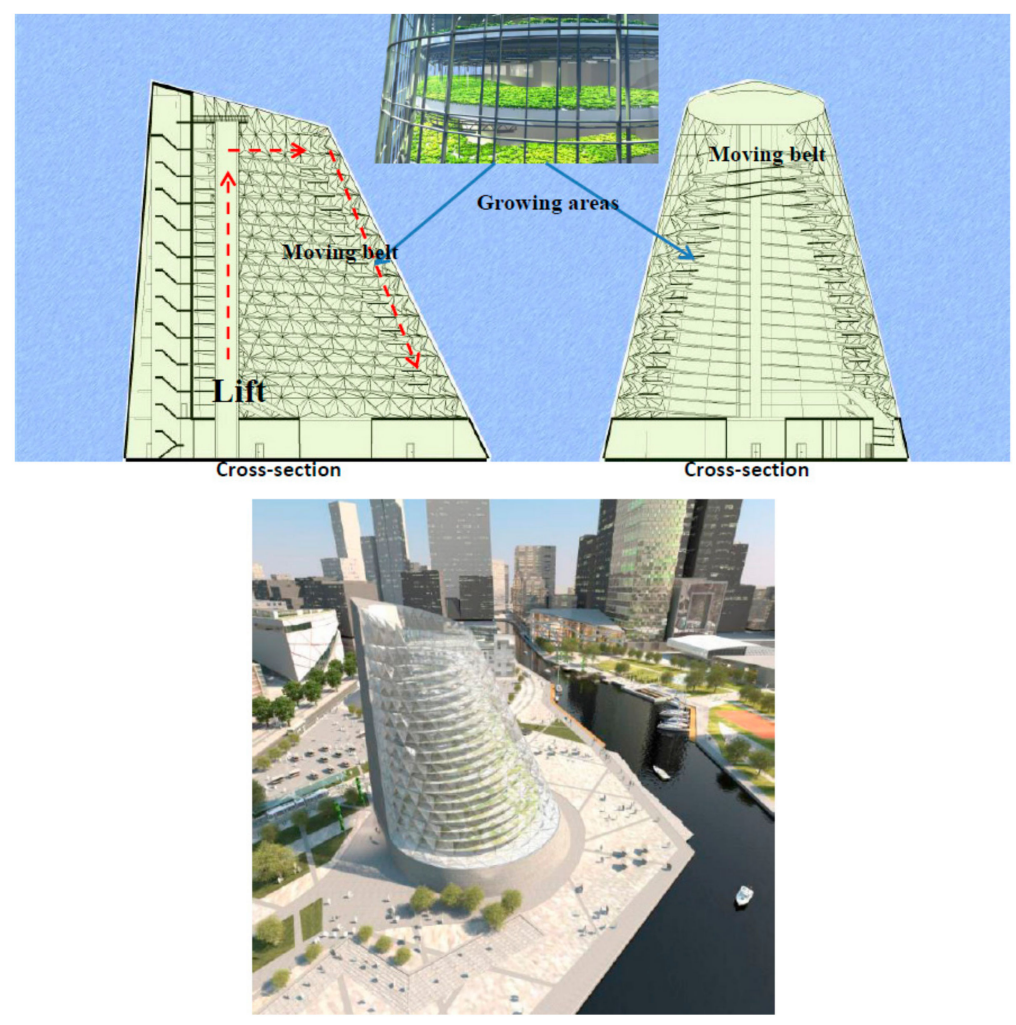

Figure 8. One of Plantagon's prototype for the vertical farm. Seeds are planted in the first floor, then carried to the top via elevators, and next moves down by the helix belt system. (Adapted from [65]).

\subsubsection{La Tour Vivante}

The French architecture firm Atelier SOA has proposed a 30-floor mixed-use vertical farm-Tour Vivante (Living Tower) - that houses farming, residences, office spaces, restaurants, and retail. The concept evokes the sense of a self-contained vertical neighborhood that enjoys autonomy and reduces travel needs between the rural and the urban, by bringing together the activities of production and consumption into one space [67]. People who live and work in the tower can enjoy proximity to fresh, ripe, and preservative-free produce while the tower's tenants provide a constant income that supports the farms. It is also possible that residents of the tower could be employed in the building to reduce travel times between home and work. Additionally, combining farming, housing, and office spaces brings together the traditionally distant rural farming experience close to residents, reconnecting them with nature. The tower's architects explain that "the separation between city and countryside, urban planning and natural areas, places of living, consumption, and production is 
increasingly problematic for sustainable land management ... The concept of Tour Vivante aims to combine agricultural production, housing and activities in a single system" [67].

The interweaving of these functions and activities aims to provide a symbiotic relationship between the inhabitants and the farming environment. For example, food waste from restaurants and residents will be collected and processed to be used as a liquid fertilizer to fruits and vegetables. Similarly, the oxygen produced by plants will be channeled to tenants, while the carbon dioxide produced by the tenants will be transferred to plants. Rainwater from the roof and the façades will be collected, filtered, and used in the farm, and the waste generated by the farm and other functions (housing, offices) will be collected and used to generate power for the tower [67].

Blackwater produced by the tower will be recycled and purified to feed and fertilize the plants. The Tour Vivante also embraces renewable energy by employing two large wind turbines, as well as photovoltaic panels, placed on the southern façade of the building and its roof. The tower will also be constructed from recycled and recyclable materials. A thermal concrete shaft at the core of the building will help to control solar gain and humidity in the building while facilitating natural ventilation through the "chimney effect" and the application of a double skin façade. Overall, the tower explores possibilities of blending architecture with agriculture, merging food production and consumption into one place [67].

\subsubsection{Harvest Green Tower}

The city of Vancouver, British Columbia, Canada, expects to face rapid urban growth in the coming decades that would result in substantial demands on food. Romses Architects has recently proposed a multifunctional vertical farm in Vancouver in support of the City's 2030 Challenge of reducing carbon emissions. The project, named "Harvest Green Tower", provides space for a mix of uses including residences, offices, entertainment, retail, restaurants, and vertical farming that will produce vegetables, herbs, fruits, fish, egg-laying chickens, goat cheese, and sheep dairy. The project also connects well with the city's public mass-transit system. The main sections of the tower are described as follows [68].

- Underground. A parking lot and shared car co-op

- Street level. A grocery store, farmer's market, restaurants, and a transit hub

- Lower floors. A livestock grazing plain, bird habitat, goat cheese, and sheep dairy facility

- Middle floors. A space for producing fruits, vegetables, and fish

- Upper floors. Residential units

- Tower's top. A large rainwater cistern

The tower will harness renewable energy by installing rooftop mounted wind turbines on the roof, photovoltaic glazing on the façade, a geothermal station underground, and bio-energy from the compost of plants and animals. All of these combined factors provide the possibility of selling surplus power back to the grid. Rainwater will be collected in a cistern atop the tower and used to irrigate plants through the downward pull of gravity. The project was a winning entry in Vancouver's 2030 Challenge given that it addressed climate change through the promotion of high-density mixed-use developments in the urban core, thereby curtailing sprawl [68].

\subsubsection{Skyfarm}

Designed by architect Gordon Graff, the Skyfarm is a 59-floor vertical farm proposed for downtown Toronto, Canada. This tower embraces the hydroponic method for growing food, using an area totaling about $743,224 \mathrm{~m}^{2}\left(8,000,000 \mathrm{ft}^{2}\right)$. It is predicted that the Skyfarm will produce the equivalent of a thousand-acre rural farm, feeding about 35,000-50,000 people per year [69]. The building will be equipped with its biogas plant that contains an anaerobic digester to produce methane from its waste, which is then burned to generate electricity. The system can also reclaim the 
waste and sewage by diverting it to the Skyfarm's anaerobic digester to produce the methane necessary to generate electricity. Furthermore, the liquid slurry extracted by the anaerobic digesters could be used by rural farms as fertilizer [69].

\subsubsection{Pyramid Farm}

Architecture professors Eric Ellingsen and Dickson Despommier have proposed a self-sustaining 30-story "Pyramid Farm" to produce a wide variety of fruits and vegetables as well as fish and poultry farm that will feed about 50,000 people annually. The project embraces a closed-loop agricultural ecosystem where nearly every element of the farming process-including water and nutrients-is recycled and re-used, minimizing waste drastically. The farm will include a heating and pressurization system that splits sewage into water and carbon, fueling machinery and electrifying lighting. Overall, the proposed farm will be efficient, as it will utilize only $10 \%$ of the water used in traditional farming techniques and only $5 \%$ of the space of a traditional farm. Finally, the visual quality of the pyramid is appealing and would fit well into an urban area [70].

\subsubsection{Vertical Farm in Philippine}

A recent visionary project proposed a vertical aeroponics farm that offers high yields of rice in the Philippines; a country that faces food insecurity and lacks farmland. Rice is a particularly valuable food not only in the Philippines but also across the globe, given that half of the world's population relies on rice as a major food source. Jin Ho Kim has proposed using aeroponics technology that uses minimal water to grow rice compactly on a terraced vertical farm to be constructed by an array of bamboo parallelograms. The project will create local jobs, supply local food, and lead to significant savings in transportation, storage, refrigeration, and packaging, eventually incorporating spaces for social gatherings and children $[70,71]$.

\section{Discussion: Opportunities and Challenges}

Vertical farming represents a proactive thinking approach that aims to ensure the sustainability of cities by addressing the issue of food security. The urban population already faces food shortages, and food prices are skyrocketing due to increases in oil prices, shortages of water and the diminishment of other agricultural resources. The current practices of supplying food to urban areas suffer from environmental and economic problems, such as the inefficient practice of transporting food great distances. As an answer to these problems, the vertical farm will grow food efficiently and sustainably by saving energy, water, and fossil fuels, reducing toxins and restoring ecosystems, as well as providing new opportunities for employment. We have seen the rapid growth of modest-scale vertical farming, and these projects have provided excellent examples of adaptive reuse of vacant industrials spaces [72-76].

Therefore, the vertical farm may offer opportunities in the three pillars of sustainability: environment, society, and economy (Table 6). It can offer a sustainable food-production model that supplies crop year-round with no interruption due to climate change, season, or adverse natural events (e.g., hurricane, drought, and flood). It has also the potential to provide greater yield per space unit-the ratio is 1:4-1:6, depending on the type of crop [77,78]. Further, the high-tech cultivation methods of the vertical farm reduce demand on potable water. They are often efficient in irrigating plants, by targeting plant roots and reducing evaporation [79]. They may also recycle wastewater (grey, even black water) and harness rainwater. When fish farms are integrated, fish removes waste (esp. fish filet). The vertical farm can also produce energy by burning methane from compost. For example, the Plant Vertical Farm in Chicago and the Republic of South Korea VF factory convert waste to energy $[80,81]$. 
Table 6. Key sustainable benefits of the vertical farm.

\begin{tabular}{|c|c|c|c|c|}
\hline$\#$ & Benefit & Environmental & Social & Economic \\
\hline 1 & $\begin{array}{l}\text { Reducing food-miles } \\
\text { (travel distances) }\end{array}$ & Reducing air pollution & $\begin{array}{l}\text { Improving air quality } \\
\text { improves environmental } \\
\text { and people's health. } \\
\text { Customers receive } \\
\text { "fresher" local food }\end{array}$ & $\begin{array}{l}\text { Reduce energy, packaging, } \\
\text { and fuel to transport food }\end{array}$ \\
\hline 2 & $\begin{array}{l}\text { Reducing water } \\
\text { consumption for food } \\
\text { production by using } \\
\text { high-tech irrigation systems } \\
\text { and recycling methods }\end{array}$ & $\begin{array}{l}\text { Reducing surface water } \\
\text { run off of traditional farms }\end{array}$ & $\begin{array}{l}\text { Making potable water } \\
\text { available to more people }\end{array}$ & Reduce costs \\
\hline 3 & Recycling organic waste & $\begin{array}{l}\text { Save the environment by } \\
\text { reducing needed land fills }\end{array}$ & $\begin{array}{l}\text { Improve food quality and } \\
\text { subsequently consumers' } \\
\text { health }\end{array}$ & Turn waste into asset \\
\hline 4 & Creating local jobs & $\begin{array}{l}\text { People do not have to } \\
\text { commute to work and } \\
\text { hence will decrease } \\
\text { ecological footprint }\end{array}$ & $\begin{array}{l}\text { Create a local community } \\
\text { of workers and social } \\
\text { networks with farmers }\end{array}$ & $\begin{array}{l}\text { Benefit local people } \\
\text { economically }\end{array}$ \\
\hline 5 & $\begin{array}{l}\text { Reduced fertilizers, } \\
\text { herbicides, and pesticides }\end{array}$ & $\begin{array}{l}\text { Improve the } \\
\text { environmental well-being }\end{array}$ & $\begin{array}{l}\text { Improve food quality } \\
\text { and subsequently } \\
\text { consumers' health }\end{array}$ & Decrease costs \\
\hline 6 & Improve productivity & Needs less space & $\begin{array}{l}\text { Reduce redundant, } \\
\text { repetitive work, } \\
\text { and save time to do } \\
\text { productive and socially } \\
\text { rewarding activities }\end{array}$ & Offer greater yields \\
\hline 7 & $\begin{array}{l}\text { Avoid crop losses due to } \\
\text { floods, droughts, hurricane, } \\
\text { over exposure to sun, and } \\
\text { seasonal changes }\end{array}$ & $\begin{array}{l}\text { Decrease environmental } \\
\text { damage and cleanups of } \\
\text { farms after damage }\end{array}$ & Improve food security & Avoiding economic loss \\
\hline 8 & $\begin{array}{l}\text { Control product/produce } \\
\text { regardless to seasons }\end{array}$ & Produce regarding season & $\begin{array}{l}\text { Increase accessibility } \\
\text { year-round and improve } \\
\text { respond to population } \\
\text { demand }\end{array}$ & $\begin{array}{l}\text { Fuel economic activities } \\
\text { year-round }\end{array}$ \\
\hline 9 & Using renewable energy & Reducing fossil fuel & Improve air quality & Reduce costs \\
\hline 10 & Bringing nature closer to city & Increase bio-diversity & $\begin{array}{l}\text { Improve health, reduce } \\
\text { stress and enhance } \\
\text { psychological well-being }\end{array}$ & Create jobs in the city \\
\hline 11 & $\begin{array}{l}\text { Promoting high-tech and } \\
\text { green industry }\end{array}$ & $\begin{array}{l}\text { "green technology" } \\
\text { reduce harm and improve } \\
\text { environmental } \\
\text { performance }\end{array}$ & $\begin{array}{l}\text { Encourage higher } \\
\text { education and generate } \\
\text { skilled workers }\end{array}$ & $\begin{array}{l}\text { Provides new jobs in } \\
\text { engineering, biochemistry, } \\
\text { biotechnology, } \\
\text { construction and } \\
\text { maintenance, and research } \\
\text { and development }\end{array}$ \\
\hline 12 & $\begin{array}{l}\text { Reducing the activities of } \\
\text { traditional farming }\end{array}$ & $\begin{array}{l}\text { Preserving natural } \\
\text { ecological system }\end{array}$ & Improve health of citizens & $\begin{array}{l}\text { Saving money } \\
\text { required to correct } \\
\text { environmental damage }\end{array}$ \\
\hline 13 & $\begin{array}{l}\text { Repurposing dilapidated } \\
\text { buildings }\end{array}$ & $\begin{array}{l}\text { Enhance the } \\
\text { environment. Remove eye } \\
\text { sores and stigma from } \\
\text { neighborhoods }\end{array}$ & $\begin{array}{l}\text { Create opportunities for } \\
\text { social interaction }\end{array}$ & Revive economy \\
\hline
\end{tabular}

When compared to traditional farming, the vertical farm may reduce the need for fossil fuel required for tractors, plows, or shipping. Traditional farming uses lots of fossil fuel; for example, conventional farming in North America consumes $20 \%$ of fossil fuel due to plowing, seeding, harvesting, fertilizing and so on [82,83]. The vertical farm can also reduce food travel distance (food-miles) by promoting "local for local" life style, i.e., distances between food production and consumption are minimized [84-86]. As mentioned earlier, in conventional farming, food travels on 
average 1500 miles. Further, the vertical farm eliminates the need of packing agricultural crops for long-distance transportation $[6,87,88]$.

Indoor farming is immune to weather change, which affects traditional farming by changing temperature, water supply, and photo intensity. These factors often reduce produce yield; for example, droughts destroy crops every year worldwide [88,89]. As such, the vertical farm will be important for food security especially as climate change threatens our cities. As mentioned earlier, Gotham Greens was the only fresh food supplier in New York during the Sandy Hurricane. Additional benefit of the vertical farm is providing an ideal growth environment for each plant that improves crop yield [62,73]. Advances in technologies, for example, the LED lighting, promises to increase yields as LED emits programmed wavelength of light for optimal photosynthesis of different types of crops. Luckily, the prices of these technologies are dropping [74]. The vertical farm provides an environment almost free of invasive pest species [90]. It also reduces, and possibly eliminates the use of mineral fertilizers, herbicides and pesticides, and nitrogen $(\mathrm{N})$ and phosphorous $(\mathrm{P})$, which have been causing environmental degradation by polluting surface water and groundwater [91-93].

The vertical farm can assist in cooling the environment, sequestering $\mathrm{CO}_{2}$, reducing the Urban Heat Island (UHI) effect, and combating climate change [94,95]. As such, it can help in reducing energy needed to cool indoor spaces in summer time and reduce carbon dioxide emission [96-98]. Further, the vertical farm can help in absorbing noise since vegetation reduces sound reflection. Vegetation and soil can function together as sound insulator $[97,99]$. When rooftop farming or green roofs are also applied, noise could be lowered further by absorbing higher frequency noise produced by auto traffic, machineries, and airplanes [99].

The vertical farm may also provide socio-economic benefits by offering employment opportunities [100]. Building a vertical farm requires a multi-disciplinary team of architects, engineers, scientists, farmers, horticulturists, environmentalists, marketers, and economists. For example, industrial, mechanical and electrical engineers will be needed to design water recycling systems, lighting systems, heating, ventilation and air conditioning (HVAC) systems, seed and plant growth monitoring and harvesting systems. Computer experts will be needed to build databases and software applications. As such, the vertical farm offers new exciting careers in biochemistry, biotechnology, construction, maintenance, marketing, engineering, and research and development opportunities for improving the involved technologies [100-102]. Further, robotics and software engineers could also be needed. Moreover, a vertical farm may include grocery stores and engage distribution centers, which provide additional work opportunities [68,103].

Further, vertical farming is likely to create new social networks and communities that forge new friendship in the workspace and beyond, among producers, farmers, and consumers [93]. In addition, vertical farmers may enjoy selling their produce directly to customers and develop friendships [104]. Vertical farms could have an important educational role in informing about plants and produce by bringing farming activities closer to city dwellers. For example, Gotham Greens in New York frequently invites visitors and students to their vertical farm and holds educational sessions [105].

Our health is directly impacted by the "freshness" and wholesomeness of food we consume and the vertical farm intends to supply quality, local organic food $[58,89]$. It could help consequently to reduce or stop the transmission of harmful infectious diseases for currently much produced food by conventional agriculture is polluted and carry bacterial diseases that endanger the lives of millions of inhabitants. That is, since the vertical farm product is not soil-based, it is likely to be not affected by polluted soil or irrigation water. Further, vertical farm's crops are rich in nutrients [106,107]. Moreover, being close to nature helps to reduce stress and has positive influence on mental health.

Notwithstanding the promising future and large potential benefits, challenges and barriers in the path to the vertical farm implementation should be noted. Research has highlighted social resistance, where masses of people do not accept the alteration of traditional farming for it is the natural way to grow food $[77,89,94,99]$. Importantly, the core argument against vertical farming is that growing food indoors requires more energy, effort, and resources than traditional farming $[86,98,100]$. That is, "It is 
much more expensive, of course, to build a vertical greenhouse than to build a normal greenhouse" [72]. Despommier acknowledges that the costs of implementing vertical farms are high, particularly the start-up costs, and he calls on the government to provide the seed money to fund these projects. Apparently, to raise the required investment capital is a challenge. In short, in order for the vertical farm to be sustainable, it must be profitable.

Further, central cities are ideal locations for vertical farms for enjoying proximity to dense population and major retail outlets [69]. However, the issue of affordability is salient in central cities where land and space are expensive. For example, central areas in major cities in Hong Kong, Australia (e.g., Melbourne, Sydney), United Kingdom (e.g., London) have very expensive real estate, which presents an economic difficulty at the commercial scale [107]. However, some major cities such as New York and Chicago have sizable stocks of vacant older properties that could be repurposed into vertical farming. This has happened in projects such as The Pant in Chicago, IL and AeroFarms in Newark, NJ [49,72].

Overall, residential, retail, office, and commercial uses of high-rises continue to be more profitable than that by agricultural activities [95]. It seems that increasing the productivity of the vertical farm is the prime factor to make it prevail in the future. "If the yield per hectare for indoor farming is much higher than rural outdoor farming, perhaps as much as up to 50 times, this factor will eventually outweigh the initial cost of land acquisition ... and assuming 50-fold improved productivity, the break-even point may well be an estimated 6-7 years" [106] (p. 295). Such production will likely to offset the startup costs including expensive land or rent. Another drawback of the vertical farm is inability to produce all types of crops. In fact, current vertical farms produce limited crops such as lettuce, tomatoes, strawberries, and to less extent, grape, and soy products. Also, produced quantities are too small. Martin's research indicates an imbalance between vertical farms' production and their catchment areas, where many of population reside in these areas are underserve. They found that in the near future, urban food will continue to come from distant rural areas $[98,107]$.

Further, due to economic reasons, most vertical farms produce and then distribute leafy greens to restaurants, and local residents remain not the prime client. In the same manner, low-value agricultural commodities such as wheat continue to be economically unviable. Therefore, the current product of vertical farms is limited in scope and quantities. Overall, production volumes of vertical farms are small, particularly when compared to "limitless" acres of traditional farming. Further, scaling up vertical farming could be costly and complex [86,108,109].

Another limitation is that current renewable energy sources, such as photovoltaics and wind turbine, produce little energy that would make it difficult not to rely on the city grid. It is only the plants at the building's perimeter and on the top level that could benefit from solar radiation [34,109]. In this regard, it is important to employ rotatable stacked arrays of plants inside each floor of a high-rise enclosure so that plants receive maximum natural light [93].

Consequently, until now, no multi-story vertical farm tower has been built, and despite copious attempts to make this a reality, the concept of the vertical farm tower remains on the drawing board. Despommier hints at a solution by stating that "High-rise food-producing buildings will succeed only if they function by mimicking ecological process, namely by safely and efficiently re-cycling everything organic, and recycling water from human waste disposal plants, turning it back into drinking water" [4] (p. 121).

\section{Conclusions}

A plethora of research and pioneering projects has demonstrated the potential of vertical farming at the pilot scale, prototypes and at the production level. The vertical farm has the potential to play a critical role in the sustainability of food in urban areas. This is most important as we project into the future when urban population will increase significantly. Vertical farming has various advantages over rural farming, observed within the three pillars of sustainability: environmental, social, and economic. New high-tech cultivation methods, including hydroponics, aeropnics and 
aquaponics, largely challenge the need for soil-based farming for a range of crops. Advancements in greenhouse and supporting technologies such as multi-racking mechanized systems, recycling systems, LED lighting, solar power, wind power, storage batteries, drones as well as computing power, software applications, databases and The Internet of Things are likely to coalesce into efficient production systems in the near future. Increasingly, there is a need for interdisciplinary research and collaboration that promote collective thinking among the various disciplines involved in creating vertical farms [110-114].

Perhaps, in the distant future, there is the prospect of developing fully automated vertical farms. And hypothetically, if vertical farms were integrated in the city, they will be able to supply food for the entire population. However, there is still a need for more developments that scale up projects so that the economic and commercial feasibility and return on investment (ROI) are offered at best rates. As such, there is a need for research that accurately assesses the ROI of various types and sizes of vertical farms. There is a need to investigate the full life-cycle analysis (LCA) and the number of years to reach parity with a traditional farm $[109,115,116]$.

The success of the vertical farm will depend not only on innovation in technologies but also on local conditions including demand on certain produce by population, availability of labors, and farming conditions. An effective organizational structure and sound leadership are also important factors. Creativity, stewardship, and inventiveness are critical ingredients for companies that venture into new businesses such as vertical farming. In a globalized world, competition is stiff, but the first to succeed may gain a competitive edge $[99,108,115]$. As such, robust and resilient business models are needed in a world characterized by increasing complexity, nonlinearity, and "glocal" exchanges of goods. According to Copenhagen Institute for Futures Studies, Instituttet for Fremtidsforskning "Tomorrow's innovative leader isn't necessarily the person in front with innovative ideas, but the one who discovers the front-runners and harvests their ideas to cultivate and nourish the innovative environment in his organization" [74]. Nevertheless, interest in vertical farming will increase as climate change prevails further and available arable land per capita declines [117].

One more serious obstacle remains; the increasing populations of developing countries. Do these countries possess the required technologies and technical expertise to implement the vertical farm? These countries are largely poor. Can we make the products of the vertical farm affordable to the poor? Furthermore, many of these poor populations live in slums, in food deserts, away from modern life. How can we make the produce of vertical farms accessible to slum populations? Ultimately, the effectiveness of vertical farming will depend on various local factors, including the demand and supply of food, urban populations and their density, technological development, culture and eating habits, water and energy supply, as well as weather conditions.

\section{Future Research}

Vertical farming is growing rapidly, and this research barely scratches the surface of long and complex endeavor. The examined projects offer catalysts to further developments. Future studies may examine other projects including, but not limited to, Green Sense Farms (Portage, Indiana and Shenzhen, China), AeroFarms (Newark, NJ, USA), Metropolis Farms (Philadelphia, PA, USA), Plenty (San Francisco, CA, USA) VerticalHarvest (Jackson, WY, USA), Lufa Farms (Montreal, QC, Canada), VertiCrop $^{\mathrm{TM}}$ (Vancouver, BC, Canada), and a new un-named project in Suwon, South Korea. Also, future research may examine specialized technologies and methods for various indoor farming systems. For example, hydroponic systems offer multiple methods, including Nutrient Film Technique (NFT), Wick System, Water Culture, Ebb and Flow (Flood and Drain), Drip Feed System and Aeroponic Systems. Further, there is a need for conducting quantitative research that gives accurate assessments of the benefits and shortcomings of various types of vertical farms. Importantly, future research should examine the issue of affordability of advanced equipment of vertical farming to developing countries. Researchers should invent, advance, and further develop local farming techniques to make vertical farm projects feasible in these countries. For example, they may invent recycling methods that reduce 
reliance on water, design local systems by capturing rainwater, and may capitalize on local solar power for providing natural light and energy.

Acknowledgments: The author would like to thank the journal's reviewers for providing helpful comments, and the staff for careful and professional work.

Conflicts of Interest: The author declares no conflict of interest.

\section{References}

1. Al-Kodmany, K. The Vertical City: A Sustainable Development Model; WIT Press: Southampton, UK, 2018.

2. Al-Kodmany, K. Eco-Towers: Sustainable Cities in the Sky; WIT Press: Southampton, UK, 2015.

3. Al-Kodmany, K.; Ali, M.M. The Future of the City: Tall Buildings and Urban Design; WIT Press: Southampton, UK, 2013.

4. Corvalan, C.; Hales, S.; McMichael, A.J. Ecosystems and Human Well-Being: Health Synthesis; World Health Organization: Geneva, Switzerland, 2005.

5. Healy, R.G.; Rosenberg, J.S. Land Use and the States; Routledge: New York, NY, USA, 2013.

6. Thomaier, S.; Specht, K.; Henckel, D.; Dierich, A.; Siebert, R.; Freisinger, U.B.; Sawicka, M. Farming in and on Urban Buildings: Present Practice and Specific Novelties of Zero-Acreage Farming (ZFarming). Renew. Agric. Food Syst. 2015, 30, 43-54. [CrossRef]

7. Despommier, D. The Vertical Farm: Feeding the World in the 21st Century; Thomas Dunne Books: New York, NY, USA, 2010.

8. Despommier, D. Farming up the city: The rise of urban vertical farms. Trends Biotechnol. 2013, 31, 388-389. [CrossRef] [PubMed]

9. Despommier, D. Encyclopedia of Food and Agricultural Ethics (Vertical Farms in Horticulture); Springer: Dordrecht, The Netherlands, 2014.

10. Touliatos, D.; Dodd, I.C.; McAinsh, M. Vertical farming increases lettuce yield per unit area compared to conventional horizontal hydroponics. Food Energy Secur. 2016, 5, 184-191. [CrossRef] [PubMed]

11. Muller, A.; Ferré, M.; Engel, S.; Gattinger, A.; Holzkämper, A.; Huber, R.; Müller, M.; Six, J. Can soil-less crop production be a sustainable option for soil conservation and future agriculture? Land Use Policy 2017, 69, 102-105. [CrossRef]

12. The United Nations. World Population Prospects: The 2017 Revision; United Nations: New York, NY, USA, 2017.

13. Mukherji, N.; Morales, A. Zoning for Urban Agriculture. Zoning Practice 3; American Planning Association: Chicago, IL, USA, 2010.

14. Katz, R.; Bradley, J. The Metropolitan Revolution. How Cities and Metropolitan Areas Are Fixing Broken Politics and Fragile Economy; The Brookings Institution: Washington, DC, USA, 2013.

15. Astee, L.Y.; Kishnani, N.T. Building integrated agriculture: Utilising rooftops for sustainable food crop cultivation in Singapore. J. Green Build. 2010, 5, 105-113. [CrossRef]

16. Säumel, I.; Kotsyuk, I.; Hölscher, M.; Lenkereit, C.; Weber, F.; Kowarik, I. How healthy is urban horticulture in high traffic areas? Trace metal concentrations in vegetable crops from plantings within inner city neighbourhoods in Berlin, Germany. Environ. Pollut. 2012, 165, 124-132. [CrossRef] [PubMed]

17. Kalantari, F.; Tahir, O.M.; Joni, R.A.; Fatemi, E. Opportunities and Challenges in Sustainability of Vertical Farming: A Review. J. Landsc. Ecol. 2017, 2, 2. [CrossRef]

18. Kalantari, F.; Tahir, O.M.; Lahijani, A.; Kalantari, S. A Review of Vertical Farming Technology: A Guide for Implementation of Building Integrated Agriculture in Cities. Adv. Eng. Forum 2017, 24, 76-91. ISSN 2234-991X. [CrossRef]

19. Martin, G.; Clift, R.; Christie, I. Urban Cultivation and Its Contributions to Sustainability: Nibbles of Food but Oodles of Social Capital. Sustainability 2016, 8, 409. [CrossRef]

20. United States Department of Agriculture. Food Desert Locator. Available online: https://www.fns.usda. gov/tags/food-desert-locator (accessed on 15 July 2017).

21. Padmavathy, A.; Poyyamoli, G. Enumeration of arthropods in context to Plant Diversity and Agricultural (Organic and Conventional) Management Systems. Int. J. Agric. Res. 2016, 6, 805-818. [CrossRef]

22. Sanyé-Mengual, E.; Cerón-Palma, I.; Oliver-Solà, J.; Montero, J.I.; Rieradevall, J. Environmental analysis of the logistics of agricultural products from roof top greenhouses in Mediterranean urban areas. J. Sci. Food Agric. 2013, 93, 100-109. [CrossRef] [PubMed] 
23. Blaustein-Rejto, D. Harvard Economist Claims Urban Farms Do More Harm Than Good. Inhabitat, 24 June 2011. Available online: http:/ / inhabitat.com/harvard-economist-claims-urban-farms-do-more-harm-than-good/ (accessed on 15 July 2017).

24. Food and Agriculture Organization (FAO). Good Agricultural Practices for Greenhouse Vegetable Crops: Principles for Mediterranean Climate Areas; FAO: Roma, Italy, 2013; Chapter 15.

25. Cho, R. Vertical Farms: From Vision to Reality. State of the Planet, Blogs from the Earth Institute, 13 October 2011. Available online: http:/ / blogs.ei.columbia.edu/2011/10/13/vertical-farms-from-visionto-reality/comment-page-1/ (accessed on 1 June 2014).

26. Wood, S.; Sebastian, K.; Scherr, S.J. Pilot Analysis of Global Ecosystems: Agroecosystems; International Food Policy Research Institute and World Resources Institute: Washington, DC, USA, 2001; p. 110. Available online: http:/ / www.wri.org/publication/pilot-analysis-global-ecosystems-agroecosystems (accessed on 15 July 2017).

27. Al-Kodmany, K. Sustainable Tall Buildings: Cases from the Global South. Int. J. Archit. Res. 2016, 10, 52-66. [CrossRef]

28. Harris, D. Hydroponics: A Practical Guide for the Soilless Grower, 2nd ed.; New Holland Publishing: London, UK, 1992.

29. Munoz, H.; Joseph, J. Hydropnics: Home-Based Vegetable Production System, Inter-American Institute for Cooperation on Agriculture (IICA). June 2010. Available online: http:/ / legacy.iica.int/Eng/regiones/caribe/ guyana/IICA\%20Office\%20Documents/Hydroponics\%20Manual/Hydroponics\%20Manual.pdf (accessed on 15 July 2017).

30. Hedenblad, E.; Olsson, M. Urban Growth Analysis of Crop Consumption and Development of a Conceptual Design to Increase Consumer Adoption of Vertical Greenhouses. Master's Thesis, Chalmers University of Technology, Gothenburg, Sweden, 2017. Available online: http:/ /www.tekniskdesign.se/download/ Hedenblad_Olsson.pdf (accessed on 15 July 2017).

31. Pullano, G. Indoor vertical grower touts concept's benefits. VGN Vegetable Grower News, 15 August 2013. Available online: http:/ / vegetablegrowersnews.com/index.php/magazine/article/indoor-vertical-growertouts-concepts-benefits (accessed on 15 July 2017).

32. Green Spirit Farms. Sustainable Vertical Farming. Available online: http://www.greenspiritfarms.com/inthe-news (accessed 15 July 2017).

33. Yeang, K. Ecoskyscrapers and ecomimesis: New tall building typologies. In Proceedings of the 8th CTBUH World Congress on Tall \& Green: Typology for a Sustainable Urban Future, Dubai, UAE, 3-5 March 2008; pp. 84-94.

34. Cooper, D. GrowCube promises to grow food with ease indoors (hands-on). Engaget, 8 November 2013. Available online: http://www.engadget.com/2013/11/08/insert-coin-growcubes-hands-on/ (accessed on 15 July 2017).

35. Barnhart, E. A Primer on New Alchemy's Solar Aquaculture. December 2017. Available online: http:/ / www. aces.edu/dept/fisheries/education/documents/Primeronsolaraquaculture_aquaponics.pdf (accessed on 15 July 2017).

36. Diver, S. Aquaponics-Integration of Hydroponics with Aquaculture, National Sustainable Agriculture Information Service. 2006. Available online: http://www.backyardaquaponics.com/Travis/aquaponic.pdf (accessed on 15 July 2017).

37. Eve, L. PlantLab Could Grow Fruit and Vegetables for the Entire World in a Space Smaller than Holland. Inhabitat, 17 March 2015. Available online: http:/ /inhabitat.com/dutch-company-plantlabs-agriculturalrevolution-could-grow-the-worlds-fruit-and-veg-in-a-space-smaller-than-holland/ (accessed 15 July 2017).

38. Levenston, M. Philips Lighting Promotes City Farming. City Farmer News, 10 December 2011. Available online: http:/ / www.cityfarmer.info/2011/12/10/ (accessed on 15 July 2017).

39. Matuszak, J. Vertical Farming Revolution Taking Root in New Buffalo. Harbor Country News, 3 July 2012. Available online: http:/ / www.harborcountry-news.com/articles/2012/07/04/features/doc4ff35c9fc8e3d166588244. txt (accessed on 15 July 2017).

40. Marks, P. Vertical Farms Sprouting All over the World. New Scientist, 16 January 2014. Available online: http:/ / www.newscientist.com/article/mg22129524.100-vertical-farms-sprouting-all-over-theworld.html\#.U1yPU_RDuao (accessed on 15 July 2017).

41. United States Environmental Protection Agency. AgSTAR: Biogas Recovery in the Agriculture Sector. Available online: https:/ / www.epa.gov/agstar (accessed on 15 July 2017). 
42. Advantages of Vertical Farming. Vertical Farming Systems. 2017. Available online: http:/ /www.verticalfarms. com.au/advantages-vertical-farming (accessed on 15 July 2017).

43. Sky Greens. Available online: https:/ / www.skygreens.com/ (accessed on 15 July 2017).

44. Aiken, M. Vertical Farming Powering Urban Food Sources. Diplomatic Courier, 3 April 2014. Available online: http:/ / www.diplomaticourier.com/news/topics/environment/2143-vertical-farming-poweringurban-food-sources (accessed on 15 July 2017).

45. Green Spirit Farms. Sustainable Vertical Farming, New Buffalo, Michigan. Available online: http:/ / www. greenspiritfarms.com/ (accessed on 15 July 2017).

46. Smiechowski, J. Vertical Farming Venture Achieves Sustainability and Success in New Buffalo, Michigan. SeedStock, 10 June 2013. Available online: http:/ / seedstock.com/2013/06/10/vertical-farming-ventureachieves-sustainability-and-success-in-new-buffalo-michigan/ (accessed on 15 July 2017).

47. Frank, L. Pennsylvania Governor Corbett Partners with Innovative Farm to Establish Operations in Lackawanna County, Creating 101 Jobs. 13 December 2013. Available online: http:/ /www.prnewswire.com/news-releases/ pennsylvania-governor-corbett-partners-with-innovative-farm-to-establish-operations-in-lackawanna-countycreating-101-jobs-235605661.html (accessed on 15 July 2017).

48. Trotter, G. FarmedHere, indoor farm in Bedford Park, turning off the lights for good. Chicago Tribune, 16 January 2017. Available online: http: / / www.chicagotribune.com/business / ct-farmedhere-closing-0117biz-20170116-story.html (accessed on 15 July 2017).

49. Meinhold, B. FarmedHere: The Nation's Largest Indoor Organic Farm Now Growing in Chicago. Inhabitat, 27 May 2013. Available online: http:/ / inhabitat.com/farmedhere-the-nations-largest-indoor-organic-farmnow-growing-in-chicago/ (accessed on 15 July 2017).

50. In a Chicago Suburb, an Indoor Farm Goes 'Mega'. Associate Press (PA), 28 March 2013. Available online: http:/ / www.cleveland.com/business/index.ssf/2013/03/in_a_chicago_suburb_an_indoor.html (accessed on 15 July 2017).

51. The Plant. Available online: http:/ / www.plantchicago.com/ (accessed on 15 July 2017).

52. Baker, S. Green Girl to Create Indoor Vertical Farm. Daily News East Memphis, 7 November 2012. Available online: http:/ / www.memphisdailynews.com/news/2012/nov/7/green-girl-to-create-indoor-verticalfarm/ (accessed on 15 July 2017).

53. Cerón-Palma, I.; Sanyé-Mengual, E.; Oliver-Solà, J.; Montero, J.I.; Rieradevall, J. Barriers and Opportunities Regarding the Implementation of Rooftop Eco.Greenhouses (RTEG) in Mediterranean Cities of Europe. J. Urban Technol. 2012, 19, 87-103. [CrossRef]

54. Sanyé-Mengual, E.; Antón, A.; Oliver-Solà, J.; Montero, J.I.; Rieradevall, J. Environmental assessment of urban horticulture structures: Implementing Rooftop Greenhouses in Mediterranean cities. In Proceedings of the LCA Food Conference, San Francisco, CA, USA, 8-10 October 2014.

55. Whittinghill, L.J.; Rowe, D.B.; Cregg, B.M. Evaluation of Vegetable Production on Extensive Green Roofs. Agroecol. Sustain. Food Syst. 2013, 37, 465-484. [CrossRef]

56. Orsini, F.; Gasperi, D.; Marchetti, L.; Piovene, C.; Draghetti, S.; Ramazzotti, S.; Bazzocchi, G.; Gianquinto, G. Exploring the production capacity of rooftop gardens (RTGs) in urban agriculture: The potential impact on food and nutrition security, biodiversity and other ecosystem services in the city of Bologna. Food Secur. 2014, in press. [CrossRef]

57. Al-Kodmany, K. Green Retrofitting Skyscrapers: A Review. Buildings 2014, 4, 683-710. [CrossRef]

58. Sanyé-Mengual, E.; Llorach-Massana, P.; Sanjuan-Delmás, D.; Oliver-Solà, J.; Josa, A.; Montero, J.I.; Rieradevall, J. The ICTA-ICP Rooftop Greenhouse Lab (RTG-Lab): Closing metabolic flows (energy, water, $\mathrm{CO}_{2}$ ) through integrated Rooftop Greenhouses. In 6th AESOP Sustainable Food Planning Conference; Roggema, R., Keefer, G., Eds.; VHL University of Applied Sciences: Utrecht, The Netherlands, 2014; pp. 692-701.

59. Plakias, A.C. The Farm on the Roof: What Brooklyn Grange Taught Us About Entrepreneurship, Community, and Growing a Sustainable Business; Avery: New York, NY, USA, 2016.

60. Brooklyn Grange. Available online: http://brooklyngrangefarm.com/ (accessed on 15 July 2017).

61. Leahy, K. Brooklyn Grange is the World's Largest Rooftop Farm! Inhabitat, 18 October 2011. Available online: http://inhabitat.com/nyc/brooklyn-grange-worlds-largest-rooftop-farm-kicks-offsecond-growing-season/ (accessed on 15 July 2017).

62. Gotham Greens. Available online: http:/ / gothamgreens.com/ (accessed on 15 July 2017). 
63. Something Unexpected Is Sprouting in Historic Chicago Neighborhood, CBS News. Available online: https: / /www.cbsnews.com/news/gotham-greens-viraj-puri-greenhouse-farm-on-roof-of-pullman-factory-chicago/ (accessed on 29 April 2016).

64. Robin Plaskoff Horton. New York City Urban Farms after Hurricane Sandy, Urban Gardens. Available online: http: / /www.urbangardensweb.com/2012/11/12/new-york-city-urban-farms-after-hurricane-sandy/ (accessed on 12 November 2012).

65. Plantagon. Available online: http:/ / plantagon.com/ (accessed on 15 July 2017).

66. Geddes, T. The Future of Vertical Farming in 5 Inspiring Examples. Dispatch Weekly, 12 October 2016. Available online: http://dispatchweekly.com/2016/10/future-vertical-farming-5-inspiring-examples / (accessed on 15 July 2017).

67. La Tour Vivante, an International Sustainable City, SOA Architects. Available online: http://www.ateliersoa. fr/verticalfarm_fr/pages/images/press_urban_farm.pdf (accessed on 15 July 2017).

68. Jordana, S. Harvest Green Project/Romses Architects. ArchDaily, 7 May 2009. Available online: http:/ / www. archdaily.com/21555/harvest-green-project-romses-architects / (accessed on 15 July 2017).

69. Alter, L. Sky Farm Proposed for Downtown Toronto. TreeHugger, 14 June 2007. Available online: http:/ / www. treehugger.com/sustainable-product-design/sky-farm-proposed-for-downtown-toronto.html (accessed on 15 July 2017).

70. Kain, A. Pyramid Farm is a Vision of Vertical Agriculture for 2060. Inhabitat, 3 June 2009. Available online: http:/ / inhabitat.com/pyramid-farm-vertical-agriculture-for-2060/ (accessed on 15 July 2017).

71. Meinhold, B. Aeroponic Vertical Farm: High-Yield Terraced Rice Paddies for the Philippines. Inhabitat, 18 March 2013. Available online: http:/ / inhabitat.com/aeroponic-vertical-farm-high-yield-terraced-ricepaddies-for-the-philipines / (accessed on 15 July 2017).

72. Fletcher, O. The Future of Agriculture May Be Up. The Wall Street Journal, 13 October 2012. Available online: http:/ / online.wsj.com/news/articles/SB10000872396390443855804577602960672985508 (accessed on 15 July 2017).

73. Despommier, D. The Vertical Essay. Available online: http://www.verticalfarm.com/?page_id=36 (accessed on 15 July 2017).

74. How to be Resilient in the 21st Century-The Radar, the Shield and the Sword, Copenhagen Institute for Futures Studies. Instituttet for Fremtidsforskning. 2012. Available online: http://cifs.dk/publications/ members-reports / (accessed on 15 July 2017).

75. Albajes, R.; Cantero-Martínez, C.; Capell, T.; Christou, P.; Farre, A.; Galceran, J.; López-Gatius, F.; Marin, S.; Martín-Belloso, O.; Motilva, M.-J.; et al. Building bridges: An integrated strategy for sustainable food production throughout the value chain. Mol. Breed. 2013, 32, 743-770. [CrossRef]

76. Sivamani, S.; Bae, N.; Cho, Y. A Smart Service Model Based on Ubiquitous Sensor Networks Using Vertical Farm Ontology. Int. J. Distrib. Sens. Netw. 2013, 9, 461-495. [CrossRef]

77. Abel, C. The vertical garden city: Towards a new urban topology. CTBUH J. 2010, 2, 20-30.

78. Eigenbrod, C.; Gruda, N. Urban vegetable for food security in cities. A review. Agron. Sustain. Dev. 2015, 35, 483-498. [CrossRef]

79. Safikhani, T.; Abdullah, A.M.; Ossen, D.R.; Baharvand, M. A review of energy characteristic of vertical greenery systems. Renew. Sustain. Energy Rev. 2014, 40, 450-462. [CrossRef]

80. Sivamani, S.; Bae, N.-J.; Shin, C.-S.; Park, J.-W.; Cho, Y.-Y. An OWL-Based Ontology Model for Intelligent Service in Vertical Farm. Lect. Notes Electr. Eng. 2014, 279, 327-332.

81. Lehmann, S. The Principles of Green Urbanism: Transforming the City for Sustainability; Earthscan: London, UK, 2010.

82. Caplow, T. Building integrated agriculture: Philosophy and practice. Urban Futur 2009, 2030, 54-58.

83. Despommier, D. The vertical farm: Controlled environment agriculture carried out in tall buildings would create greater food safety and security for large urban populations. J. für Verbraucherschutz und Leb. 2011, 6, 233-236. [CrossRef]

84. Cicekli, M.; Barlas, N.T. Transformation of today greenhouses into high technology vertical farming systems for metropolitan regions. J. Environ. Prot. Ecol. 2014, 15, 1779-1785.

85. Grewal, S.S.; Grewal, P.S. Can cities become self-reliant in food? Cities 2012, 29, 1-11. [CrossRef]

86. Voss, P.M. Vertical Farming: An agricultural revolution on the rise. Master's Thesis, Halmstad University, Halmstad, Sweden, 2013. 
87. Besthorn, F.H. Vertical Farming: Social Work and Sustainable Urban Agriculture in an Age of Global Food Crises. Aust. Soc. Work 2013, 66, 187-203. [CrossRef]

88. Sauerborn, J. Skyfarming: An alternative to horizontal croplands. Resour. Eng. Technol. A Sustain. World 2011, $18,19$.

89. Wagner, C.G. Vertical farming: An idea whose time has come back. Futurist 2010, 44, 68-69.

90. Graber, A.; Schoenborn, A.; Junge, R. Closing water, nutrient and energy cycles within cities by urban farms for fish and vegetable Production. Int. Water Assoc. Newsl. 2011, 37, 37-41.

91. Dubbeling, M. Integrating urban agriculture in the urban landscape. Urban Agric. Mag. 2011, 25, 43-46.

92. Sivamani, S.; Kwak, K.; Cho, Y. A Rule Based Event-Driven Control Service for Vertical Farm System. In Future Information Technology; Park, J.J., Stojmenovic, I., Choi, M., Xhafa, F., Eds.; Springer: Berlin/Heidelberg, Germany, 2014; Volume 276, pp. 915-920.

93. Specht, K.; Siebert, R.; Thomaier, S.; Freisinger, U.; Sawicka, M.; Dierich, A.; Henckel, D.; Busse, M. Zero-Acreage Farming in the City of Berlin: An Aggregated Stakeholder Perspective on Potential Benefits and Challenges. Sustainability 2015, 7, 4511-4523. [CrossRef]

94. Specht, K.; Siebert, R.; Hartmann, I.; Freisinger, U.B.; Sawicka, M.; Werner, A.; Thomaier, S.; Henckel, D.; Walk, H.; Dierich, A. Urban agriculture of the future: An overview of sustainability aspects of food production in and on buildings. Agric. Hum. Values 2014, 31, 33-51. [CrossRef]

95. World Agriculture: Towards 2015/2030. An FAO perspective, FAO Corporate Document Repository. 21 August 2017. Available online: http:/ / www.fao.org/docrep/005/y4252e/y4252e06.htm (accessed on 15 July 2017).

96. Banerjee, C.; Adenaeuer, L. Up, Up and Away! The Economics of Vertical Farming. J. Agric. Stud. 2014, 2, 40. [CrossRef]

97. Al-Chalabi, M. Vertical farming: Skyscraper sustainability? Sustain. Cities Soc. 2015, 18, 74-77. [CrossRef]

98. Ellis, J. Agricultural Transparency: Reconnecting Urban Centres with Food Production. Master's Thesis, Dalhousie University, Halifax, NS, USA, 2012.

99. Kadir, M.Z.A.A.; Rafeeu, Y. A review on factors for maximizing solar fraction under wet climate environment in Malaysia. Renew. Sustain. Energy Rev. 2010, 14, 2243-2248. [CrossRef]

100. Saadatian, O.; Lim, C.H.; Sopian, K.; Salleh, E. A state of the art review of solar walls: Concepts and applications. J. Build. Phys. 2013, 37, 55-79. [CrossRef]

101. Glaser, J.A. Green chemistry with nanocatalysts. Clean Technol. Environ. Policy 2012, 14, 513-520. [CrossRef]

102. Perez, V.M. Study of the Sustainability Issue of Food Production Using Vertical Farm Methods in an Urban Environment within the State of Indiana. Master's Thesis, Purdue University, West Lafayette, IN, USA, 2014.

103. Al-Kodmany, K. Sustainable Tall Buildings: Toward a Comprehensive Design Approach. Int. J. Sustain. Des. 2012, 2, 1-23.

104. Germer, J.; Sauerborn, J.; Asch, F.; de Boer, J.; Schreiber, J.; Weber, G.; Müller, J. Skyfarming an ecological innovation to enhance global food security. J. für Verbraucherschutz und Leb. 2011, 6, 237-251. [CrossRef]

105. Al-Kodmany, K. Guidelines for Tall Buildings Development. Int. J. High-Rise Build. 2012, 1, 255-269.

106. La Rosa, D.; Barbarossa, L.; Privitera, R.; Martinico, F. Agriculture and the city: A method for sustainable planning of new forms of agriculture in urban contexts. Land Use Policy 2014, 41, 290-303. [CrossRef]

107. Ali, M. M.; Al-Kodmany, K. Tall Buildings and Urban Habitat of the 21st Century: A Global Perspective. Build. J. 2012, 2, 384-423. [CrossRef]

108. Benke, K.; Tomkins, B. Future food-production systems: Vertical farming and controlled-environment agriculture. Sustain. Sci. Pract. Policy 2017, 13, 13-26. [CrossRef]

109. Kim, H.-G.; Park, D.-H.; Chowdhury, O.R.; Shin, C.-S.; Cho, Y.-Y.; Park, J.-W. Location-Based Intelligent Robot Management Service Model Using RGPSi with AoA for Vertical Farm. Lect. Notes Electr. Eng. 2014, 279, 309-314.

110. Lam, S.O. Urban Agriculture in Kingston: Present and Future Potential for Re-Localization and Sustainability. Master's Thesis, Queen's University, Kingston, ON, Canada, 2007.

111. Liu, X. Design of a Modified Shipping Container as Modular Unit for the Minimally Structured \& Modular Vertical Farm (MSM-VF). Master's Thesis, The University of Arizona, Tucson, AZ, USA, 2014.

112. Al-Kodmany, K. The Logic of Vertical Density: Tall Buildings in the 21st Century City. Int. J. High-Rise Build. 2012, 1, 131-148. 
113. Al-Kodmany, K. Tall Buildings, Design, and Technology: Visions for the Twenty-First Century City. J. Urban Technol. 2011, 18, 113-138. [CrossRef]

114. Al-Kodmany, K. Eco-Iconic Skyscrapers: Review of New Design Approaches. Int. J. Sustain. Des. 2010, 1, 314-334.

115. Tan, Z.; Lau, K.K.-L.; Ng, E. Urban tree design approaches for mitigating daytime urban heat island effects in a high-density urban environment. Energy Build. 2015. [CrossRef]

116. Nochian, A.; Mohd Tahir, O.; Maulan, S.; Rakhshandehroo, M. A comprehensive public open space categorization using classification system for sustainable development of public open spaces. ALAM CIPTA. Int. J. Sustain. Trop. Des. Res. Pract. 2015, 8, 29-40.

117. Kalantari, F.; Mohd Tahir, O.; Golkar, N.; Ismail, N.A. Socio-Cultural Development of Tajan Riverfront, Sari, Iran. Adv. Environ. Biol. 2015, 9, 386-392.

(C) 2018 by the author. Licensee MDPI, Basel, Switzerland. This article is an open access article distributed under the terms and conditions of the Creative Commons Attribution (CC BY) license (http://creativecommons.org/licenses/by/4.0/). 